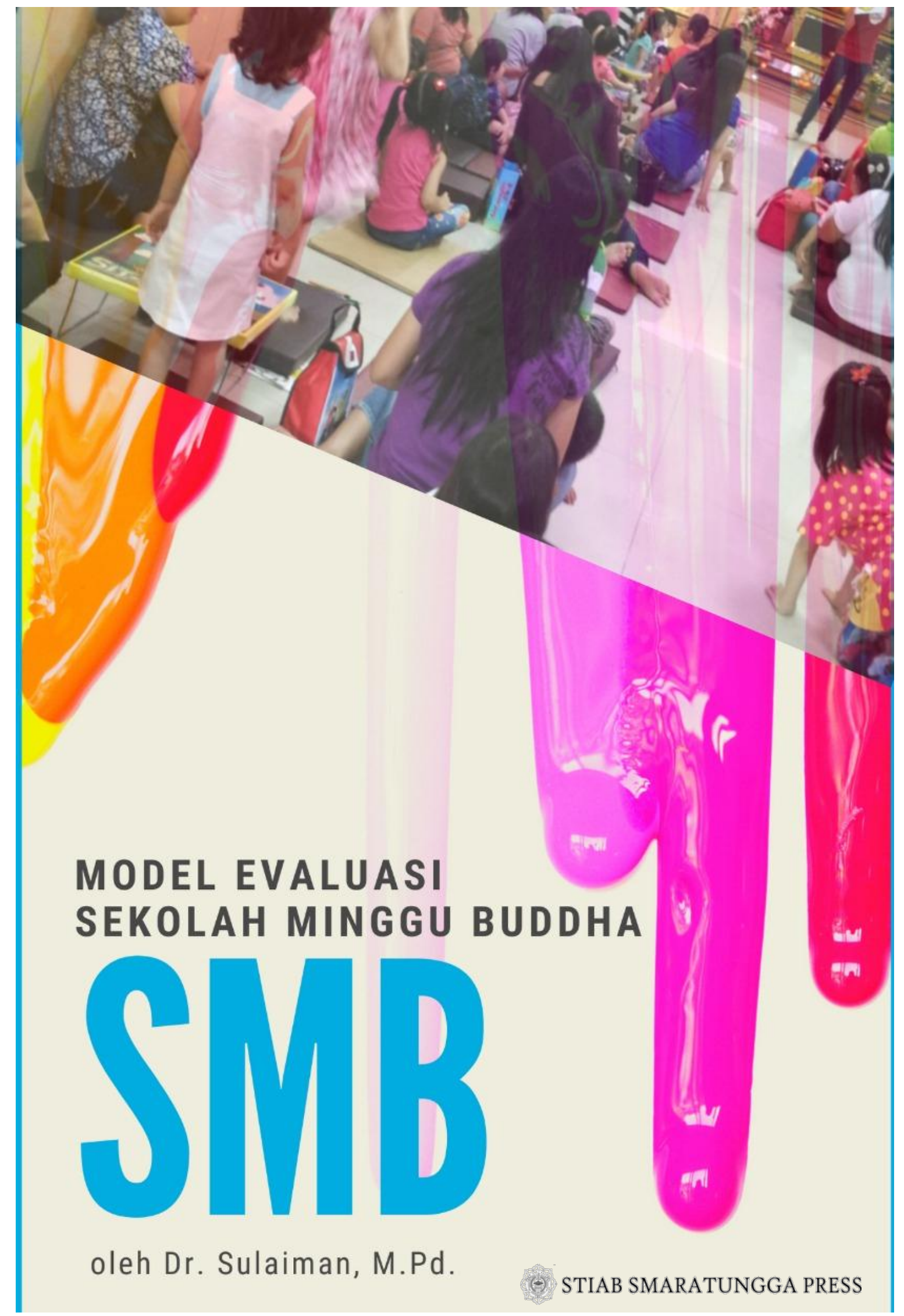




\title{
Model Evaluasi \\ Sekolah Minggu Buddha \\ (SMB)
}

\author{
Dr. Sulaiman Girivirya, M.Pd.
}

Terima kasih mendalam kepada

Yth. Bapak/ Ibu Guru, Kakak Pembina SMB, Mahasiswa PAB, Pemerhati Pendidikan, dan Orangtua Siswa SMB atas antusias serta perhatian terhadap

Pendidikan Buddha.

Untuk mendapatkan Buku Elektronik (e-PUB; PDF)“Evaluasi Sekolah Minggu Buddha" ini, GRATIS, sedangkan untuk buku cetak dengan menghubungi admin mengganti ongkos cetak (berwarna) dan ongkos kirim sebesar Rp138.000,-

Silahkah klik tautan buku elektronik GRATIS berikut:

https://drive.google.com/drive/folders/1quG_0P-kmUbh4-xJbnEvx7YzjNZhbRO5? usp=sharing

Agar kami dapat mendedikasikan diri sepenuhnya untuk membangun komunitas kreatif demi kemajuan Pendidikan, Bapak/lbu/Saudara dapat berpartisipasi mengembangkan kepedulian dan kedermawanan dengan disalurkan ke rekening Yayasan Grahanyana No. 1185-01-000222-56-8, Bank Rakyat Indonesia (BRI).

Terima kasih,

Salam a

\section{STIAB SMARATUNGGA PRESS}

Desember 2019 
Model Evaluasi Sekolah Minggu Buddha

ISBN

: 978-602-52670-7-9

Penulis $\quad$ : Dr. Sulaiman Girivirya M.Pd.

Penelaah Ahli : Prof. Dr. H. Djaali

Prof. Dr. Moch. Asmawi, M.Pd.

Prof. Dr. Martini Jamaris, M.Sc.Ed.

Prof. Dr. Ma'ruf Akbar, M.Pd.

Prof. Dr. dr. Myrnawati Crie Handini, MS.PKK.

Prof. Dr. Yufiarti, M.Pd.

Prof. Dr. dr. Fasli Jalal, Ph.D.,SpGK.

Dr. Elindra Yeti, M.Pd.

Desain sampul : Sureno, S.Kom.

Penerbit : STIAB Smaratungga Press

Redaksi : Sekolah Tinggi Ilmu Agama Buddha (STIAB) Smaratungga Ampel, Boyolali, Jawa Tengah 57352

Cetakan Pertama, Desember 2019

Hak cipta dilindungi undang-undang

Dilarang memperbanyak karya tulis ini dalam bentuk dan dengan cara apapun tanpa ijin tertulis dari penerbit 


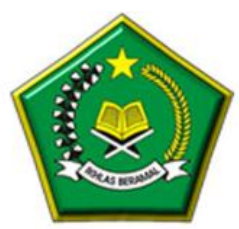

SAMBUTAN DIRJEN BIMAS BUDDHA

KEMENTERIAN AGAMA REPUBLIK INDONESIA

Penulis dari hasil penelioan tersebut dapat membantu dalam penyeienggaraen Sekolah Minggu Buddha (SMB). Hasil studi craluasi seperti ini dapat memberican sebuah deskripsi dan eksistensi proses penyelenggaraan Sekolah Minggu Buddha (SMB) yang sampai saat ini baru memilib Poturjuk Teknis (Jubnis) Peryelenggaraan Sekolah Minggu Buddha (SMB).

Kajan IImiah berupa temuan-semuan peneloan ovaluasi dari pemerhati pendidican Buddha semacam ini, dapa: memberikan kontribusi nyata dalam bentuk pemōöran terhadap Pemerintah. Datam uparya poringkasan kualtas pendidkan keagamaan Buddha melaki jalur pendidkan Sekolah Minggu Buddha (SMB). Direktorat Jenderal Bimas Budona Kementerian Agama Republik Indonesia masih menyiapkan beberapa Regulasi, soperti :

1. Penetapan Pedoman Perryelenggaraan Pendidkan Sekclah Minggu Busdha (SMB) di Indonesia;

2. Penetapan Kurikulum Pendidikan Sekolah Minggu Buddha (SMB) di Indonesia:

3. Penetapan Silabus Pendidikan Sekclah Minggu Buddha (SMB) di Indonesia:

4. Penecapan Tensga Pendidk dalam Peryenggaraan Pendidican Sekolah Minggu Buddha (SMB) di Indonesia:

5. Penetapan Buku Teles dan Buku pendukung Pendidikan Sekolah Minggu Buddha (SMB) di indonesia.

Sehingga melalui penetapan-penetapan regulasi penyenggaraan Seikclah Minggu Buddha (SMB) tersebut diharaplcan akan dapat mewijudkan kualicas pendidikan keagamaan Buddha molalui jalur pendidican nonformal.

Pada akhirnya, Direitora: Jenderal Bimas Euddha Kementerian Agama RI, dalam hal ini memberkan apresiasi yang setinggi-tingginya dan mengucapkan torima kash kepada Penuls, acas tersusunry Podoman ini melalui sebuah penelitian. Semoga dapat berguna dan menjaci kontribusi bagi pemerintah solaku Rogulator yang pada sast ini juga masih memylapican beberapa komponen-komponen reglasi penyelemggaraan pendidkan Sekclah Minggu Buddha (SMB).

Demikian sambusan ini, semoga semua makhluk hidup berbahagia.

Terimalcasin....

Nomo Buctoraya.

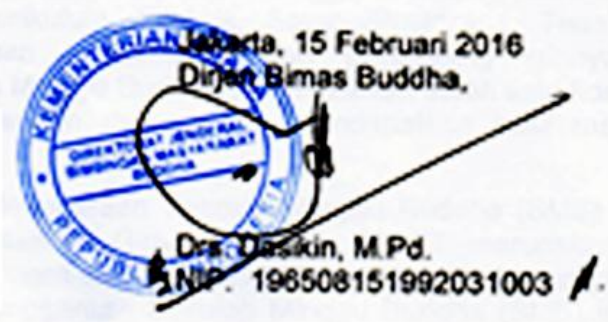




\section{Prakata}

Semenjak kebangkitan kembali agama Buddha di Indonesia yang ditandai dengan ditasbiskannya putra Indonesia pertama, The Boan An (YM. Mahathera Ashin Jinarakhita) sebagai biksu di Myanmar (Birma pada saat itu) perlahanlahan ajaran pencerahan ini dikenal kembali. Pelaksanan sekolah minggu buddha di Indonesia digerakan oleh masyarakat buddhis bertujuan memperkenalkan nilai-nilai ajaran Buddha. Dimulai usia dini hingga kegiatan para lansia yang diadakan di Cetiya, Wihara, atau TITD. Sedangkan di pemerintahan, perhatian pada perkembangan pendidikan Buddhis sudah terasa sejak awal perkembangan agama buddha di Indonesia hingga terbitnya Peraturan Menteri Agama nomor 39 tahun 2014 tentang Pendidikan Keagamaan Buddha.

Sehubungan dengan itulah untuk mewujudkan kulitas pendidikan yang dituangkan pada peraturan menteri agama tesebut baik pendidikan formal maupun nonformal maka diperlukan dukungan dari berbagai pihak untuk melaksanakan, menyempurnakan dan mengawasi pendidikan keagamaan buddha. Salah satu upaya itu adalah dengan disusunnya Pedoman Pelaksanaan Sekolah Minggu Buddha Anak Usia dini (Adi Sekhal Paud sejenis) ini. Buku ini disusun berdasarkan Studi Evaluasi Pelaksanaan Program Sekolah Minggu Buddha di Kota Tangerang tahun 2015.

Semoga dengan hadirnya buku ini dapat memberikan manfaat bagi lembaga sekolah minggu buddha diseluruh Indonesia. Untuk menjadi perhatian bersama; Direktorat Jenderal Bimbingan Masyarakat Buddha, Lembaga Pendididikan Tinggi Agama Buddha dan Para simpatisan agar terus mengembangkan pendidikan nilai-nilai universal, Buddha Dharma, bagi masyarakat Buddhis sehingga memberi manfaat kedamaian, kemakmuran dan kebahagiaan kepada masyarakat Indonesia yang majemuk ini.

Jakarta, Desember 2019

Dr. Sulaiman Girivirya,M.Pd. 


\section{UCAPAN TERIMA KASIH}

1. Direktorat Jenderal Bimbingan Masyarakat Buddha

2. Program Doktoral Universitas Negeri Jakarta

3. Lembaga Pengelola Dana Pendidikan (LPDP)

4. Bimas Buddha Provinsi Banten

5. Wihara Dhammaphala Tangerang

6. Wihara Dhammaratna Tangerang

7. Wihara Dharmasubha Tangerang

8. Wihara Inderaloka Tangerang

9. Wihara Jetavana Tangerang

10. Wihara Nimmala Tangerang

11. Wihara Punna Sampada Tangerang 


\section{Adi Segha}

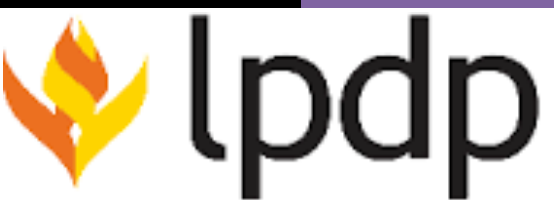

lembaga pengelola dana pendidikan
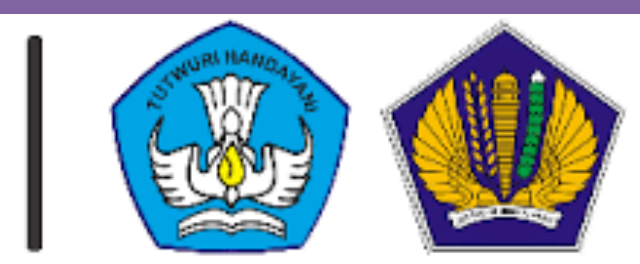

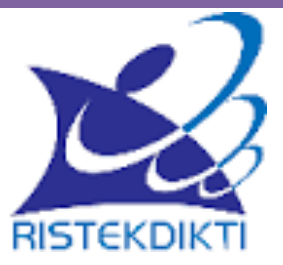

SEJARAH: UUD 1945 mengamanahkan bahwa sekurang-kurangnya dua puluh persen Anggaran Penerimaan dan Belanja Negara (APBN) adalah untuk fungsi pendidikan. Pemerintah dan DPR RI pada tahun 2010 melalui UU Nomor 2 tahun 2010 tentang APBN-P 2010 menyepakati bahwa sebagian dana dari alokasi dana fungsi pendidikan dalam APBN-P tersebut dijadikan sebagai Dana Pengembangan Pendidikan Nasional (DPPN) yang dikelola dengan mekanisme pengelolaan dana abadi (endowment fund) oleh sebuah Badan Layanan Umum (BLU).

Pada tahun 2011, Menteri Keuangan dan Menteri Pendidikan dan Kebudayaan menyepakati bahwa pengelolaan DPPN dan pemanfaatan hasil pengelolaan dana tersebut akan dilaksanakan oleh Kementerian Keuangan namun pejabat dan pegawainya merupakan gabungan antara pegawai Kementerian Keuangan dan pegawai Kementerian Pendidikan dan Kebudayaan.

Menteri Keuangan melalui Peraturan Menteri Keuangan (PMK) Nomor 252/PMK.01/2011 tanggal 28 Desember 2011 menetapkan Organisasi dan Tata Kelola Lembaga Pengelola Dana Pendidikan sebagai sebuah lembaga non eselon yang langsung bertanggung jawab kepada Menteri Keuangan dan berpedoman pada kebijakan-kebijakan yang ditetapkan oleh Dewan Penyantun LPDP (Menteri Pendidikan dan Kebudayaan, Menteri Keuangan, Kemenristek DIKTI dan Menteri Agama). Melalui Keputusan Menteri Keuangan (KMK) Nomor 18/KMK.05/2012 tanggal 30 Januari 2012, LPDP ditetapkan sebagai instansi pemerintah yang menerapkan pola keuangan Badana Layanan Umum.

BEASISWA: Beberapa beasiswa yang diberikan oleh Lembaga Pengelola Dana Pendidikan (LPDP) yaitu Beasiswa Magister dan Doktor, Beasiswa Tesis dan Disertasi, Beasisa Afirmasi, Beasiswa Spesialis Kedokteran dan Presidential Scholarship. Info lengkap dapat mengunjungi laman: Ipdp.kemenkeu.go.id 


\title{
DOA DEDIKASI
}

Segala pencapaian, serta sebab-sebab kebahagiaan dari terbitnya buku ini saya dedikasikan sepenuhnya kepada:

\author{
Almarhum Abah Ujang Efendi \\ Ummi Hj.Sumardiana \\ Papa Kheng Aseng \\ Mama Epi Hasan \\ Mendiang Svargasta YM. Mahabhiksu Vajragiri \\ Saudara-saudara monastikku Giriksanti, Joti, Panna dan Nanda \\ Ibu Yenni Djaenap \\ Bapak Kosim Tasmin \\ Keluarga Besar Jolen (Papi Jonathan dan Ibu Ellen) \\ Prof.Martini Jamaris \\ Prof.Ma'ruf Akbar \\ Prof.Can. Myrnawati \\ Bu Can. Dr.Elindra \\ Hj.Sulastri,Lc.,M.Pd.I. \\ Susanto,S.Pd.I. \\ Sumiati,S.Si. \\ Bala Mitta Songo \\ Yusniati \\ SAHABAT SEPERJUANGAN PAUD ASIK 2012 \\ Keluarga Besar Cellfood $\AA$ (Pak Erwin dan Ibu Darwati)
}

Semua pihak yang turut membantu dan tidak dapat saya sebutkan satu persatu. Seiring doa semoga Anda senantiasa sehat dan berbahagia. 


\section{DAFTAR ISI}

Sambutan Dirjen Bimas Buddha .............................................................. i

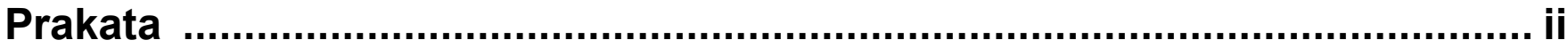

Ucapan Terima Kasih ................................................................................ ii

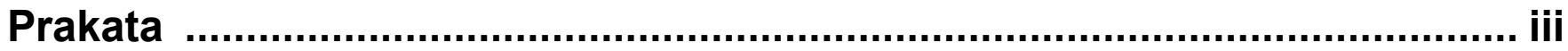

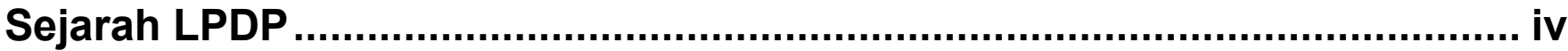

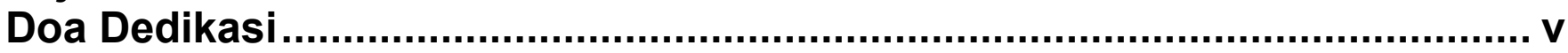

Daftar Isi ................................................................................................... vi

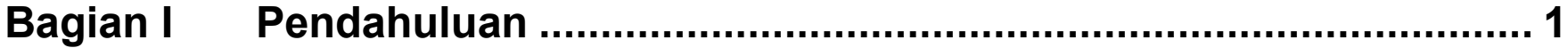

A. Latar Belakang .............................................................. 1

B. Pengertian ................................................................... 2

C. Dasar Hukum ............................................................... 2

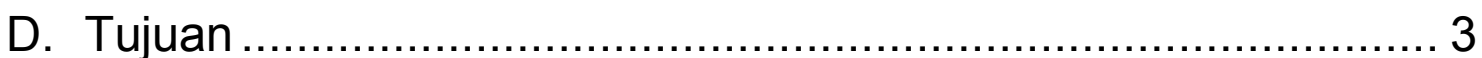

Bagian II Penyelenggaraan Sekolah Minggu Buddha .............................. 4

(Adi Sekhal Anak Usia Dini, 2-8 tahun) ...................................... 4

A. Konteks (context) ....................................................... 4

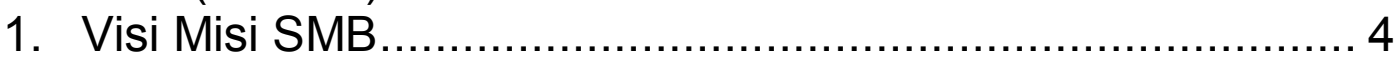

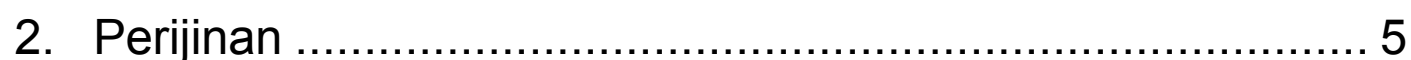

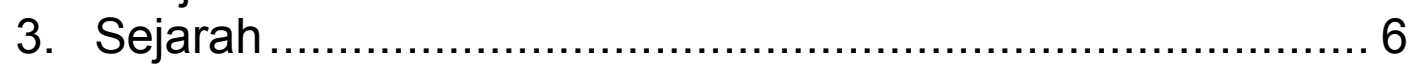

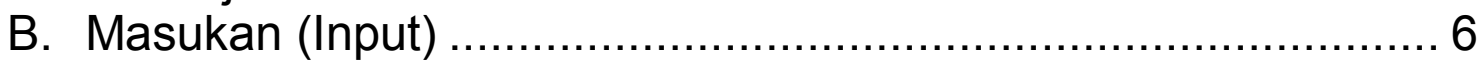

1. Tanggung Jawab Pengelola SMB ................................ 7

2. Kurikulum dan Prinsip Penyelenggaraan SMB.................. 8

3. Karakteristik Guru atau Pembina SMB ............................. 8

4. Peserta Didik ........................................................... 9

5. Sarana dan Prasarana.................................................. 9

6. Pembiayaan ............................................................ 10

C. Proses (Process) ........................................................ 10

1. Perencanaan Pembelajaran ....................................... 11

2. Teknis Pembelajaran ................................................. 12

D. Produk (Product) ........................................................... 18

E. Dampak (outcome) ...................................................... 19

Bagian III Penutup.

Lampiran 1 Contoh Surat Izin Operasional SMB...................................... 21

Lampiran 2 Contoh Format Formulir Peserta Didik SMB .............................. 22

Lampiran 3 Contoh Format Surat Tanda Serta Belajar ................................. 23 
Lampiran 4 Contoh Rencana Pembelajaran Bulanan ................................... 24

Lampiran 5 Contoh Format Buku Induk Anak SMB ..................................... 25

Lampiran 6 Contoh Format Daftar Hadir Anak SMB .................................... 26

Lampiran 7 Contoh Format Buku Pengelola dan Pendidik SMB .................... 27

Lampiran 8 Contoh Format Daftar Hadir Pengelola SMB ............................... 28

Lampiran 9 Contoh Format Kartu Dana Paramitha Bulanan SMB .................... 29

Lampiran 10 Contoh Format Buku KAS SMB ….......................................... 30

Lampiran 11 Contoh Format Buku Inventaris SMB ..................................... 31

Lampiran 12 Contoh Laporan Perkembangan Anak Sekolah Minggu Buddha... 32

Lampiran 13 Contoh Ruang Kelas, Ruang Guru dan Aktivitas Belajar

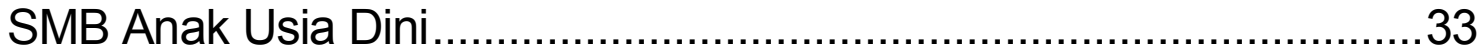

DAFTAR REFERENSI ............................................................................ 38

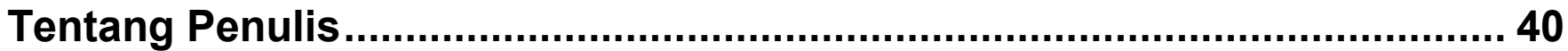


"Tugas utama AGAMA adalah MENGANGKAT DERAJAT manusia dari KEMISKINAN dan KEHINAAN."

GUS DUR/ Dr. (H.C.) K.H. Abdurrahman Wahid, Presiden Republik Indonesia yang keempat.

Bhineka Tunggal Ika Tanhana Dharma Mangrwa 


\section{Bagian I \\ Pendahuluan}

\section{Latar Belakang}

Perkembangan intelektual anak, berdasarkan hasil riset para ahli, terjadi sejak lahir hingga di usia 4 tahun sama banyaknya dengan perkembangan intelektual anak di usia 4 tahun hingga 8 tahun. Perkembangan intelektual dari usia 4 tahun hingga 8 tahun lebih banyak dari pada usia 8 tahun hingga 18 tahun. Artinya lonjakan perkembangan di usia dini sangat penting dalam keseluruhan tahapan perkembangan anak. Tidak berulang pada periode berikutnya maka dari itulah disebut sebagai usia emas. Oleh karenanya pembentukan dasar-dasar karakter spiritual yang dibutuhkan untuk berhubungan dengan sesama manusia sangat sesuai jika dilakukan sejak usia dini. Demikian pula nilai-nilai religius harusnya ditanamkan sejak dini. Rangsangan pendidikan yang diberikan sesuai dengan potensi anak dapat dikembangkan secara konsisten, bertahap, dan cukup waktu, sehingga memeberikan manfaat kepada anak di masa mendatang. Disamping itu, penting pula memberikan kebutuhan lain seperti asupan gizi seimbang, kesehatan, perlindungan, dan kasih sayang.

Program sekolah minggu buddha awalnya dilaksanakan masyarakat secara swadaya. Bertempat di wihara dengan menggunakan ruangan apa adanya.Umumnya tempat yang digunakan adalah Dharmasala. Sekolah minggu sendiri diadakan oleh masyarakat Buddhis untuk memberikan pengenalan kepada anak dalam pembiasaan sikap religius atau ritual (pujabhakti), sesuai dengan tradisi masing-masing sekolah (mazhab) serta mengenal simbol-simbol agama buddha. Pembelajaran dilakukan melalui kegiatan bermain, bernyanyi dan ceramah. Di Indonesia sendiri lembaga yang cukup terkoordinasi dengan baikuntuk kegiatan pembinaan anak-anak sekolah minggu adalah dari badan koordinasi pembina sekolah minggu, IPGABI (Ikatan Pembina Gelanggang Anak Buddhis Indonesia). Kegiatan ini dibawah binaanorganisasi kepemudaanan Buddhis yang cukup tua di Indonesia bernama Sekber PMVBI (Pemuda Buddhayana).

Pemerintah dalam hal ini Kementerian Agama, semenjak terbentuknya Direktorat Jenderal Bimbingan Masyrakat Buddha cukup memberikan perhatian dalam pembinaan sekolah minggu buddha. Terlepas dari kekurangan yang masih dilengkapi oleh Dirjen Bimas Buddha dalam pembinaan sekolah minggu Buddha, buku hasil Studi Evaluasi Program Sekolah Minggu ini, dapat dijadikan 
sebagai pelengkap dalam pelaksanaan Sekolah Minggu Buddha di Indonesia dan dapat dikembangkan kembali.

\section{Pengertian}

Pendidikan Anak Usia Dini (PAUD) adalah suatu upaya pembinaan yang ditujukan kepada anak sejak lahir sampai dengan usia enam tahun yang dilakukan melalui pemberian rangsangan pendidikan untuk membantu pertumbuhan dan perkembangan jasmani dan rohani agar anak memiliki kesiapan dalam memasuki pendidikan lebih lanjut (UU No.20 tahun 2003). Dari sisi usia, anak usia dini ditafsirkan berbeda dalam menentukan rentang usia yang dikategorikan sebagai anak usia dini. Pandangan Nasional Association for The Education of Young Children (NAEYC) misalnya menyatakan bahwa anak usia dini adalah anak yang berada pada rentang usia 0 sampai dengan 8 tahun.

Direktorat Jenderal Bimbingan Masyarakat Buddha mendefinisikan (1) Sekolah Minggu Buddha adalah unit atau lembaga berbentuk pendidikan non formal; (2)Sekolah Minggu Buddha adalah lembaga Pendidikan Keagamaan Buddha pada jalur pendidikan non formal dalam bentuk program Sekolah Minggu Buddha, dan bentuk lain yang sejenis; (3) Sekolah Minggu Buddha merupakan pendidikan non formal yang diselenggarakan oleh Masyarakat Buddha dan Majelis Keagamaan Buddha bertempat di Vihara, Cetya, atau tempat yang sesuai yang diperuntukkan khusus bagi Sekolah Minggu Buddha dalam rangka meningkatkan kualitas keimanan dan ketaqwaan.

Berdasarkan studi evaluasi di Kota Tangerang tahun 2015, Sekolah minggu buddha merupakan bentuk pendidikan keagamaan nonformal yang diselenggarakan masyarakat buddhis untuk menumbuh kembangkan nilai-nilai ajaran Buddha pada diri anak dan dibina oleh Direktorat Jenderal Bimbingan Masyarakat Buddha.

\section{Dasar Hukum}

Awalnya Pelaksanaan sekolah minggu buddha dilaksanakan oleh masyarakat sebelum dibina secara menyeluruh oleh Direktorat Jenderal Bimbingan Masyarakat Buddha. Salah satu organisasi budhis yang memiliki wadah persatuan pembina atau guru sekolah minggu buddha bernama Ikatan Pembina Gelanggang Anak Buddhis Indonesia (IPGABI). Tercatat didirikan pada tahun 1995 saat Sarasehan dan Temu Karya ke VIII di Taman Mini Indonesia Indah Jakarta wadah organisasi kepemudaan Sekber PMVBI (Pemuda Buddhayana). Dasar hukum pelaksanaan sekolah minggu ini sendiri adalah: 
1. Undang-undang nomor 20 tahun 2003 tentang Sistem Pendidikan Nasional, pasal 30 tentang Pendidikan Keagaman.

2. Peraturan Pemerintah nomor 55 tahun 2007 tentang Pendidikan Agama dan Pendidikan Keagamaan.

3. Peraturan Menteri Agama nomor 39 tahun 2014 tenang Pendidikan Keagamaan Buddha

4. Surat Keputusan Direktur Jenderal Bimbingan Masyarakat Buddha nomor DJ.VI./97/SK/2009 tentang Petunjuk Teknis Penyelenggaraan Sekolah minggu buddha (SMB)

\section{Tujuan}

1. Digunakan sebagai buku pegangan pelatihan Sekolah minggu buddha khususnya SMB Anak Usia Dini.

2. Pedoman Pelaksanaan Program Sekolah minggu buddha ini disusun berdasarkan studi evaluasi di Kota Tangerang tahun 2015, diharapkan dapat menjadi pacuan bagi lembaga pelaksana program sekolah minggu buddha di seluruh Indonesia maupun pihak-pihak yang berkepentingan.

3. Menjadi acuan dalam pelaksanaan program sekolah minggu buddha berdasarkan beberapa komponen seperti konteks, masukan, proses, produk, dan dampak pengiring.

4. Memberikan wahana umum bagi pelaksanaan PAUD sejenis dikalangan masyarakat buddhis sehingga memiliki keterarahan pelaksanaan program.

5. Aspek lebih lanjut dari pedoman ini misalkan terkait kurikulum yang lebih luas tetap mengacu pada ketentuan perkembangan oleh Dirjen Bimas Buddha. 


\section{Bagian II \\ Sekolah Minggu Buddha}

Beberapa komponen yang disarankan dalam pelaksanaan sekolah minggu buddha pada buku pedoman ini terdiri dari komponen konteks; yang menitik beratkan pada proses perencanaan untuk menggambarkan kondisi sekolah minggu buddha, komponen masukan; yang menitik beratkan pada pengorganisasian yang bertujuan untuk merancang, komponen proses menunjukkan pelaksanaan untuk menggunakan atau membuktikan strategi dalam pelaksanaan sekolah minggu buddha dan komponen produk untuk mengkaji ulang suatu pencapaian program sekolah minggu. Sedangkan di sisi komponen dampak, artinya lembaga bersama-sama dengan orang tua murid bekerjasama dalam upaya proses terjadinya kebiasaan keagamaan Buddha yang telah diajarkan di sekolah minggu dapat berkelanjutan di rumah secara kontekstual.

\section{A. Konteks (context)}

Pada komponen konteks terdiri dari visi dan misi apa yang ditetakan oleh sekolah minggu sebagai langkah awal dalam melaksanakan program sekolah minggu buddha; Dasar hukum yang menunjang dan; Pemaparan sejarah pendirian sekolah minggu buddha.

\section{Visi Misi SMB}

Menentukan visi dan misi sangatlah penting untuk melihat kearah mana program sekolah minggu buddha diarahkan. Visi merupakan gambaran besar yang terdapat pada program sekolah minggu buddha terkait tujuan dan nilai apa yang ingin dicapai. Sedangkan misi merupakan langkahlangkah pencapaian yang ingin dikembangkan untuk mewujudkan program sekolah minggu buddha yang berdasarkan kebutuhan dan nilai-nilai ajaran Buddha. Biasanya dituangkan kembali dalam bentuk tujuan program. Berikut ini contoh visi misi sekolah minggu buddha secara umum khusunya pada pembelajaran anak usia dini: 


\section{Contoh:}

Visi:

Generasi Emas Berkarakter Buddhis Sejak Usia Dini

Misi:

1. Menggalipembelajaran berbasis kecerdasan spiritual berdasarkan nilai-nilai karakter ajaran Buddha Etika dan Estetika Buddhis (Panca Dharma).

2. Membangun hidup berkesadaran.

3. Mempelajari sikap bijaksana Buddha secara kontekstual.

Tujuan:

1) Mengembangkan kreatifitas anak melalui pembelajaran yang menggunakan kecerdasan jamak untuk meningkatkan kecerdasan spiritual berdasarkan nilai-nilai etika dan estetika buddhis

2) Melatih kebiasaan (habituation) anak untuk melatih kesabaran anak dalam kehidupan sehari-hari

3) Memahami (kognitif), merasakan (afektif) dan melakukan (psikomotor) kebiasaan-kebiasaan baik sesuai ajaran Buddha.

\section{Perijinan}

Meskipun sekolah minggu buddha merupakan program pendidikan nonformal yang telah berjalan cukup lama saat ini diperlukan perijinan yang jelas. Perijinan dilakukan sesuai dengan peraturan perundangan yang berlaku dalam hal ini pejabat yang berwenang adalah Direktorat Jenderal Bimbingan Masyarakat Buddha. Hal ini dilakukan untuk keperluan pembinaan dalam rangka memberikan layanan terbaik serta perlindungan kepada masyarakat.

Berdasarkan Surat Keputusan Direktorat Jenderal Bimbingan Masyarakat Buddha nomor 220 tahun 2010, syarat-syarat mendapatkan Ijin Operasional Sekolah Minggu Buddha/SMB adalah sebagai berikut:

a. Surat permohonan dari sekolah minggu yang bersangkutan ditujukan kepada Dirjen Bimas Buddha di Jakarta

b. Melampirkan surat keputusan/penetapan tentang sekolah Minggu Buddha dari yayasan/ organisasi/ Lembaga pendiri tersebut

c. Melampirkan surat keterangan domisili sekretariat/ tempat aktivitas dari Lurah/Kepala desa/ RW setempat

d. Melampirkan Anggaran Dasar (AD) dan Anggaran Rumah Tangga (ART) 
e. Melampirkan Program Umum Sekolah Minggu, Program Tahunan

f. Melampirkan data siswa, guru dan jadwal kegiatan sekolah minggu buddha

g. Melampirkan foto copy KTP seluruh pengurus inti (minimal ketua, sekretaris dan bendahara)

h. Melampirkan pas foto terbaru Ketua Sekolah Minggu Buddha sejumlah dua (2) lembar ukuran $4 \times 6 \mathrm{~cm}$, berwarna latar belakang merah untuk wanita dan biru untuk laki-laki

Selanjutnya surat ijin operasional ini menjadi syarat diterbitkannya Surat Tanda Daftar Sekolah Minggu Buddha.

\section{Sejarah}

Ajaran Buddha sesungguhnya semangat yang terkandung dalam istilah pendidikan itu sendiri. Memberikan penerangan di dalam gulita. Pendidikan untuk menjadikan manusia menjadi manusia. Manusia sendiri berasal dari bahasa Sanskerta yang artinya makhluk yang berbudi luhur. Apa yang telah diajarkan oleh Guru Para Dewa dan Manusia, Sidharta Gautama, yang disebut Dhamma, merupakan sebuah sistem pendidikan secara holistik. Untuk saat ini dimana ajaran Buddha tidak lagi diajarkan oleh sang Guru maka pembelajaran yang dilakukan oleh masyarakat sangat baik jika dilakukan saat anak usia dini. Di banyak cetiya dan wihara, banyak wihara yang memulai kegiatan sekolah minggu buddha sebelum adanya kegiatan lain, pujabhakti umum misalnya. Kegiatan sekolah minggu buddha dapat menjadi sebuah bukti sejarah dimulainya suatu kegiatan besar hingga menjadi wihara. Maka sangat penting untuk dapat mencatat tentang keterlaksanaan program pembelajaran sekolah minggu buddha dikarenakan hal ini dapat menjadi tolok ukur berkembangnya suatu kegiatan pembinaan umat di wihara.

\section{B. Masukan (Input)}

Pada komponen masukan, terdiri dari 1) tanggung jawab kepala dan wakil kepala sekolah minggu buddha; 2) Kurikulum dan Prinsip Penyelenggaraan Sekolah minggu buddha (SMB); 3) Peserta Didik; 4) Karakteristik Guru atau Pembina Sekolah minggu buddha; 5) Sarana dan Prasarana; dan 6) Pembiayaan. Komponen ini dapat dikembangkan berdasarkan kemampuan masing-masing sekolah minggu buddha secara maksimal berdasarkan juknis Dirjen Bimas Buddha tentang sekolah minggu Buddha. 


\section{Tanggung Jawab Pengelola SMB}

Pengelola sekolah minggu buddha minimal dilaksanakan oleh kepala sekolah dan wakil kepala sekolah. Memiliki tanggung jawab penuh terhadap pelaksanaan sekolah minggu buddha. Dapat ditunjuk dan didukung sepenuhnya oleh pengurus yayasan, wihara maupun mejelis sesuai dengan bidang minimal yang dimiliki terutama memiliki pemahaman aspek pedagogi, kepemimpinan dan nilai-nilai ajaran Buddha. Tugas dan tanggung jawab kepala dan wakil kepala sekolah secara bersama-sama adalah sebagai berikut:

\section{Kepala Sekolah}

1) Menyusun program kerja sekolah minggu Buddha

2) Mengatur kegiatan belajar mengajar

3) Mengatur pelaksanaan hasil belajar

4) Mengatur bimbingan penyuluhan

5) Melaksanakan pembinaan kesiswaan

6) Melaksanakan bimbingan dan penilaian bagi guru dan tenaga kependidikan

7) Melaksanakan penyelenggaraan administrasi Sekolah minggu buddha terkait ketenagaan, keuangan, kesiswaan, perlengkapan, kurikulum dan perpustakaan dibuktikan dengan dokumen pendukung

8) Merencanakan pengembangan, pendayagunaan dan pemeliharaan sarana dan prasarana

9) Merencanakan hubungan sekolah dengan lingkungan, orang tua dan atau masyarakat

10) Melaksanakan fungsi pemeliharaan keamanan, ketertiban, dan suasana keagamaan

\section{Wakil Kepala Sekolah}

1) Mengatur dan mengawasi siswa

2) Mengatur penyusunan bahan pengajaran dan pengembangan kurikulum

3) Melaksanakan pengawasan kewenangan mengajar guru, dan pengembangan mutu staf

4) Mengatur pemakaian, pemeliharaan dan perbaikan, serta pengembangan sarana dan prasarana

5) Membina dan mengembangkan kegiatan kerjasama dengan komite sekolah 


\section{Kurikulum dan Prinsip Penyelenggaraan SMB}

Muatan materi utama yang terdapat dalam pembelajaran SMB sekurangkurangnya terdapat (1) Riwayat Hidup Buddha Gotama; (2) Kitab Suci Tripitaka; (3) Sila; (4) Samadhi; (5) Tata Cara Pujabhakti; (6) Cerita Jataka. Materi ini dapat di kembangkan kembali ke dalam pembelajaran yang sederhana sesuai dengan aspek perkembangan anak usia dini. Dalam proses pembelajarannya pengelola dan guru sekolah minggu buddha harus memperhatikan aspek-aspek terkait pelaksanaan sekolah minggu buddha usia dini seperti berikut:

1) Berdasarkan pada nilai-nilai etika dan estetika yang bersumber dari ajaran Buddha

2) Berorientasi pada kebutuhan anak

3) Pembelajaran dilakukan melalui bermain

4) Anak Sebagai pembelajar aktif

5) Menyediakan lingkungan yang mendukung proses belajar

6) Mendorong semua aspek perkembangan anak secara menyeluruh

7) Lingkungan di sekitar sebagai sumber belajar

8) Mengembangkan potensi kecerdasan hidup anak

9) Menumbuhkan semangat kebhinekaan sejak usia dini

\section{Karakteristik Guru atau Pembina SMB}

Guru dalam agama Buddha merupakan komponen penting pada sistem pembelajaran. Dari zaman Buddha Gotama masih hidup 2500-an tahun yang lalu, Beliau sendiri disebut sebagai seorang Guru, penghapus kegelapan (batin). Seorang pendidik atau pembina sekolah minggu buddha wajib memiliki kompetensi sebagai pendidik anak usia dini dan atau memiliki kemauan belajar dan kemampuan memahami kriteria sebagai pendidik anak usia dini. Guru sekolah minggu ada yang memiliki kualifikasi pendidikan agama buddha. Sedangkan pembina sekolah minggu biasanya relawan yang masih duduk di bangku sekolah minimal SMP atau SMA. Meskipun tidak semua Guru maupun Kakak Pembina SMB memiliki kualifikasi pendidikan keguruan anak usia dini khususnya, namun kualitas utama yang harus dimiliki seorang Guru adalah bekerja dengan penuh dedikasi, kecintaan akan pekerjaan sebagai pendidik (passion) dan bertekad terus meningkatkan kemampuan. Dengan honor maupun tanpa honor tetap menjunjung tinggi nilai-nilai dedikasi yang tinggi. Sebaiknya, kualifikasi seorang guru sekolah 
minggu anak usia dini (Adi Sekha) yang dapat diterapkan pada lembaga SMB adalah sebagai berikut:

1) Berpendidikan minimal SMA sederajat

2) Memiliki sertifikat pelatihan/pendidikan/pelatihan pembina sekolah minggu buddha usia dini

3) Sehat jasmani dan rohani

4) Menyukai anak kecil

5) Memahami tugas perkembangan anak

6) Berdedikasi tinggi dengan komitmen yang tinggi

7) Berkepribadian baik

8) Bersedia bekerjasama dengan pengelola, rekan guru, dan orang tua siswa

Guru maupun kakak pembina sekolah minggu buddha memiliki tugas yang sama seperti guru pada umumnya yaitu (1) merencanakan program pembelajaran; (2) melaksanakan proses pembelajaran; (3) Melaksanakan evaluasi perkembangan anak; dan (4) melakukan bimbingan, pengasuhan, dan perlindungan anak didik.

\section{Peserta Didik}

1) Peserta didik tidak dibedakan suku, kedudukan ekonomi, jabatan atau penghasilan orang tua calon siswa

2) Peserta didik sekolah minggu buddha anak usia dini yangdapat menerima pelayanan berusia 2 hingga 6 tahun atau 8 tahun yang berasal dari keluarga buddhis.

\section{Sarana dan Prasarana}

Sarana dan prasarana yang mendukung kegiatan sekolah minggu buddha utamanya adalah adanya gedung utama Dharmasala karena pembiasaan pertama yang akan ditanamkan kepada anak-anak adalah mengenal pembacaan kitab suci, dan simbol-simbol agama buddha yang terdapat di ruang Dharmasala. Selain itu jika memungkinkan kelengkapan lain seperti ruangan bermain, ruang pengelola sekolah minggu buddha, toilet untuk umum dan anak sera ruangan lainnya yang relevan untuk anak-anak. Perabot lainnya seperti alat permainan bertema Buddhis, tempat memajang hasil karya anak. 


\section{Pembiayaan}

Seyogyanya, pembiayaan dalam sekolah minggu buddha memiliki administrasi yang lazim digunakan di sekolah PAUD pada umumnya untuk meningkatkan kualitas pelayanan. Pembiayaan program SMB yang dapat dijalankan dengan berkoordinasi kepada pihak yayasan, pengurus majelis/wihara dan orang tua antara lain mencakup:

1) Perawatan sarana dan prasarana

2) Pembelian dan perawatan alat permainan edukasi bertema buddhis

3) Biaya operasional kegiatan

4) Biaya beban (listrik, air dan telepon)

5) Peningkatan keterampilan pengelola dan pendidik

6) Intensif pengelola dan pendidik

7) dan biaya lain sesuai dengan kebutuhan

Pembiayaan program sekolah minggu buddha ini dapat bersumber dari:

1) luran orang tua

2) Sumbangan donatur

3) Bantuan pemerintah

4) Bantuan pihak lain yang tidak mengikat

5) Dana awal dapat dibuat proposal rintisan

Yayasan atau pengurus wihara atau majelis harus menyadari pentingnya arti pendidikan nilai-nilai spiritual buddhis. Sehingga fokus utama pembiayaan terhadap pendidikan dapat dilakukan secara maksimal. Dengan mengembangkan pendidikan, khususnya sekolah minggu buddha, artinya yayasan, pengurus wihara atau pun majelis telah meletakkan fondasi ajaran buddha secara nyata.

\section{Proses(Process)}

Pada komponen proses, memaparkan rencana pembelajaran, teknis pembelajaran dan penilaian hasil belajar. Beberapa sekolah minggu buddha meskipun mereka memiliki keterbatasan ruangan untuk belajar, namun tetap membedakan tempat belajar yang terpisah untuk digunakan oleh kelompok anak usia dini 2 hingga 8 tahun. Ruang yang berbeda dari anak-anak kelompok usia 9 hingga 13 tahun. Artinya secara alami meskipun sebagian sekolah minggu buddha tidak memiliki tenaga ahli anak usia dini para pengelola sekolah minggu 
buddha memahami pola belajar yang berbeda. Hanya saja rata-rata pegelola sekolah minggu tidak terlalu peduli atau tidak memahami bagaimana proses penilaian perkembangan keagamaan dan lainnya pada anak usia dini. Maka pada komponen ini diberikan pedoman tentang rencana, pelaksanaan dan penilaian hasil belajar

\section{Perencanaan Pembelajaran}

Pengelola sekolah minggu buddha dapat mengelompopkkan anak sesuai usia anak secara umum dilihat dari usia kalender agar memudahkan proses pembelajaran. Tentunya didukung pula dengan kesiapan mental anak. Untuk anak usia dini dalam hal ini dapat dimulai dari usia 2 hingga 8 tahun. Sebagai contoh, SMB Wihara Dhammaratna Tangerang, ruang kelasnya cukup.Pengelola memisahkan anak usia 2 hingga 5 tahun ke dalam satu kelas dan usia 5 hingga 6 tahun kedalam satu kelompok. Ada wihara dikarenakan kekurangan ruangan digunakanlah jadwal belajar yang bergantian.

Alat-alat permainan edukasi yang berciri khas buddhis pun harus disiapkan. Mengingat pembelajaran anak usia dini adalah bermain. Gunakan bahan yang aman bagi anak, tidak membahayakan kesehatan anak. Menarik perhatian anak dan dapat dimainkan anak dengan berbagai macam cara. Murah dan bisa didapatkan di lingkungan sekitar. Tempatkan permainan ini pada tempat tertentu atau jika memiliki keterbatasan ruangan gunakan box kontainer yang terbuat dari plastik sehingga dapat dipindahkan dan disusun rapi.

Dalam merencanakan program sekolah minggu buddha, pengelola dibantu guru dapat menyiapkan buku-buku administrasi yang diperlukan misalnya:

1) Buku induk anak

2) Buku data pengelola dan pendidik

3) Daftar hadir pengelola, pendidik dan anak perkelompok

4) Buku rencana belajar minggu

5) Buku catatan perkembangan anak/uraian pembelajaran

6) Kartu iuran anak

7) Daftar rekapitulasi penerimaan dana paramita.

8) Buku kas dan buku inventaris

9) Buku daftar pengisi undangan sesuai kompetensi

10) Buku tamu 
Hal lain yang juga boleh diperhatikan adalah adanya penyusunan rencana kegiatan pembelajaran yang mengacu pada standar yang ditentukan oleh Direktur Pendidikan Dirjen Bimas Buddha. Rencana kegiatan mencakup tujuan, isi dan rencana pengelolaan program serta kegiatan. Recana kegiatan sekolah minggu bisa berupa (1) Rencana kegiatan hari minggu (2)

Rencana kegiatan bulanan dan (3) Rencana kegiatan semester. Rencana kegiatan ini dapat disusun dengan mengacu pada Permendiknas no.58 tahun 2009, juknis Pelaksanaan Program Sekolah Minggu Buddha, Dirjen Bimas Buddha no.DJ6/97/SK/2009. Penjabaran rencana pembelajaran dapat memuat tema, indikator, konsep, dan kosa kata yang akan dikembangkan. Bukan hanya sekedar kegiatan apa yang akan dilakukan di hari minggu tanpa tujuan yang jelas. Akan tetapi, kegiatan pembelajaran yang dilakukan dengan ukuran yang jelas.

\section{Teknis Pembelajaran}

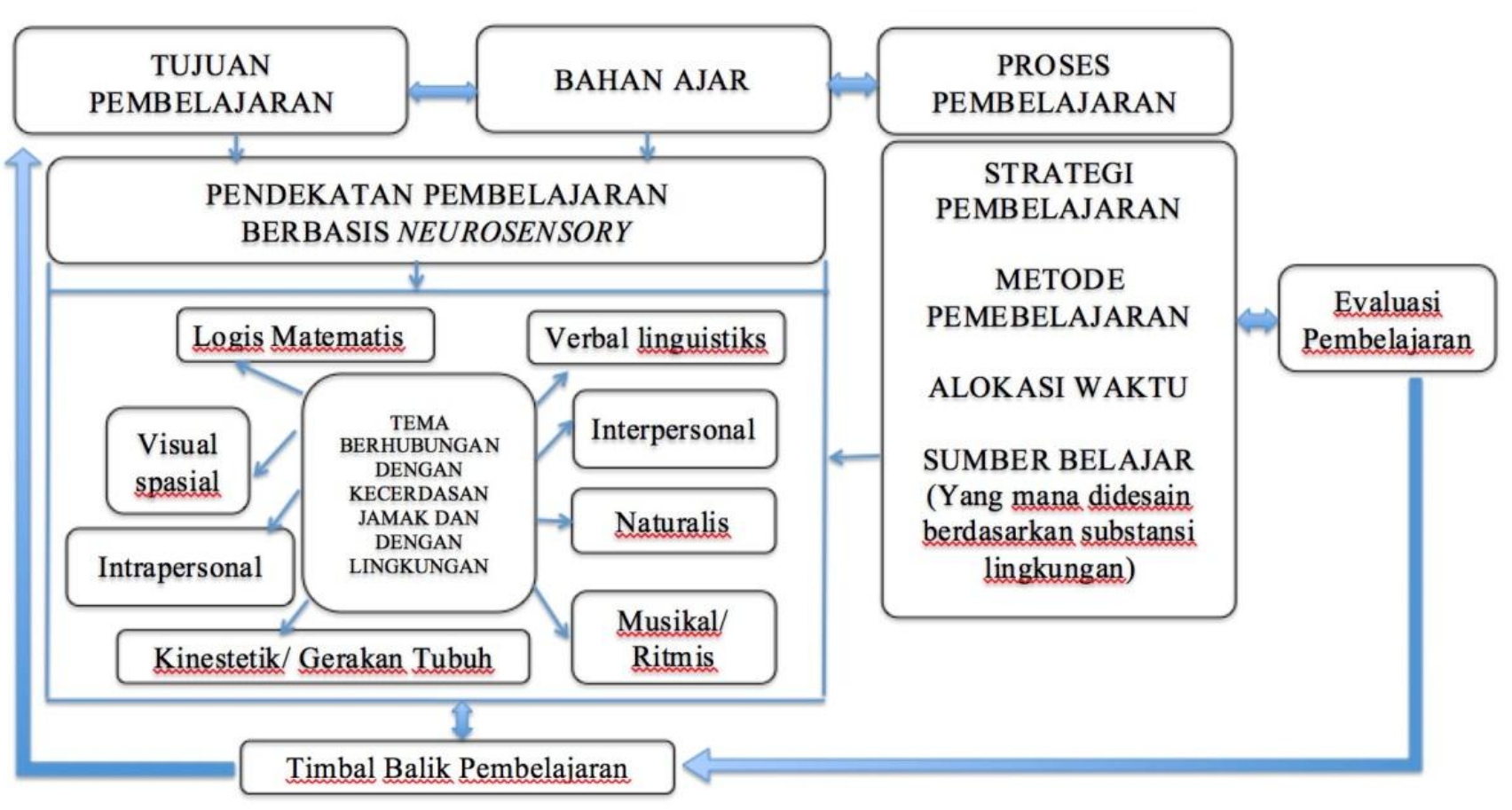

Sumber: American Journal of Educational Research, 20014 Vol.2 No. 12, 1164-1174 
Pengelola sekolah minggu buddha bersama-sama dengan guru atau pembina mendesain pembelajaran melalui bermain. Kegiatan pembelajaran dapat terintegrasi dengan berbagai pola kecerdasan majemuk. Model desain pembelajarannya dapat dikembangkan dari model yang di ungkapkan oleh Martini Jamaris (2014:1171) dalam diagram Martini Jamaris Multiple Inteligences Intergrated Instructional Model yang dapat disesuaikan ke dalam pembelajaran sekolah minggu buddha.

Sebagai contoh untuk mengembangkan kecerdasan Visual/Spasial siswa dilatih membuat gambar menggunakan lukisan jari (finger painting) dengan tema ajaran Buddha yang diambil dari Jataka. Setelah guru menjelaskan cerita Jataka, guru memberikan kesempatan kepada siswa untuk menggambarkannya dalam bentuk lukisan yang melatih siswa untuk berimajinasi dan melatih membuat gambar. Begitu pula penyatuan dengan kecerdasan lainnya yang terdiri dari kecerdasan verbal linguistik, kinestetik, intrapersonal, musikal, interpersonal, naturalis, dan logis matematis.

Sebagai contoh, secara umum pengelola bersama guru dapat menerapkan alur kegiatan sekolah minggu buddha sebagai berikut: 
Kedatangan Peserta di Wihara/SMB

Guru atau orang tua membimbing anak Meletakkan persembahan makanan ke Altar bernamaska Buddha

\section{Jurnal (Waktu Tunggu 10-20 menit)}

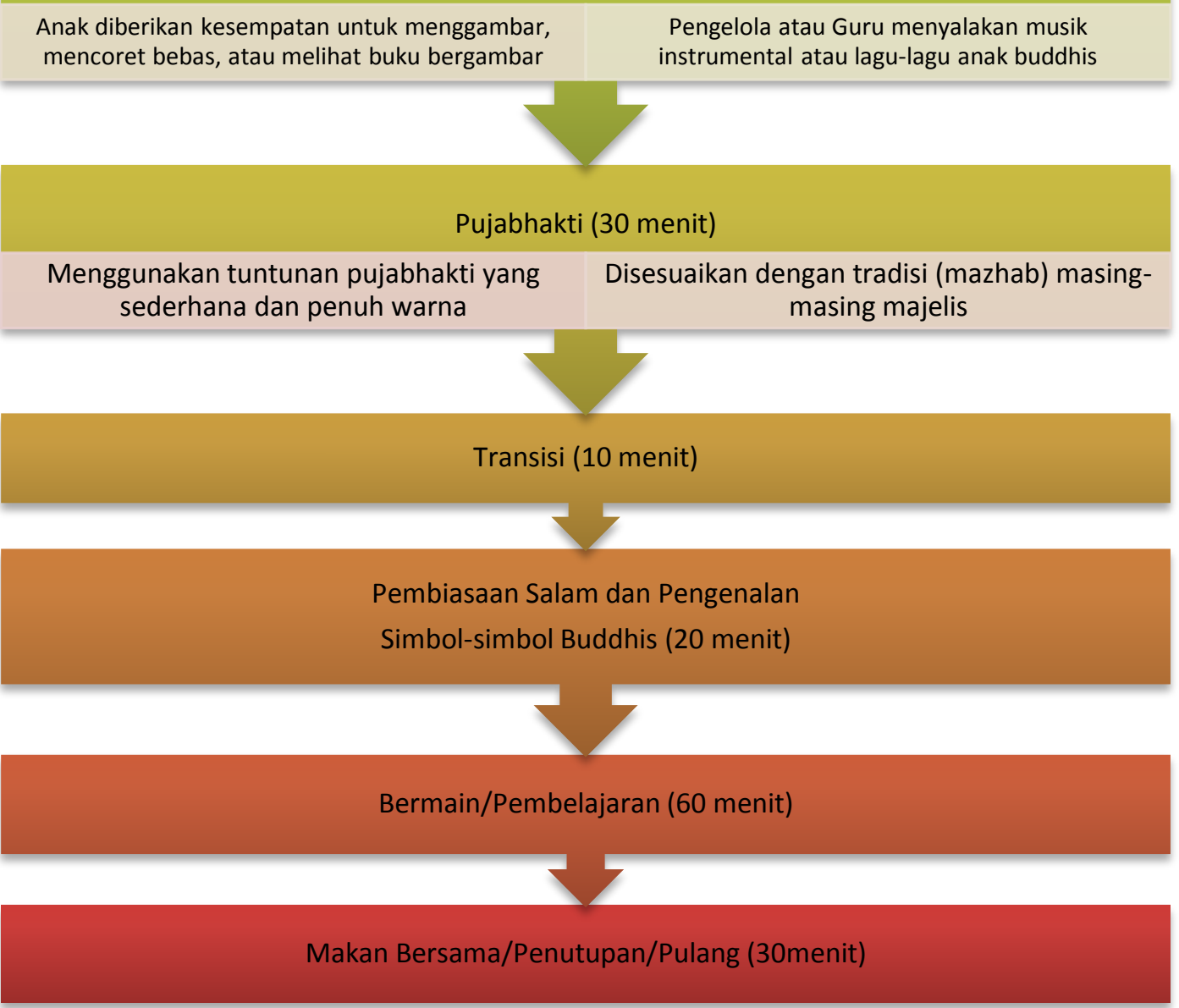

Intinya, proses pembelajaran sekolah minggu buddha anak usia dini (Adi Sekha) sesungguhnya untuk mengenal keluhuran ajaran Buddha yang dapat diterapkan dalam kehidupan sehari-hari secara kontekstual. Hal ini merupakan fondasi yang harus diisi dalam tahapan perkembangan anak. Penerapannya harus memperhatikan karakteristik pembelajaran anak usia dini. Setelah di 
sekolah minggu buddha pembelajaran dilanjutkan pada pola kebiasaan beragama Buddha dirumah bersama-sama dengan orang tua.

Sehingga apa yang dilakukan di sekolah minggu buddha dapat terinternalisasi kedalam diri anak.

\section{Penilaian Pembelajaran}

Untuk mengukur keberhasilan tujuan yang ingin dicapai dalam program sekolah minggu buddha maka diperlukan penilaian perkembangan keagamaan buddha pada anak. Dalam sekolah minggu buddha ini tentunya perkembangan yang dinilai adalah pengetahuan, dan sikap spiritual yang berbasis nilai-nilai agama buddha yang terintegrasi pada diri anak. Penilaian yang dilakukan pada anak usia dini bisa berupa penilian autentik. Dimana penilaian dilakukan secara alami. Baik berdasarkan kondisi nyata yang muncul dari perilaku anak selama proses kegiatan yang terjadi maupun hasil dari kegiatan yang dilakukan anak. Penilaian ini dilakukan oleh guru sebagai penilai (assessor) yang juga berfungsi sebagai fasilitator maupun fungsi lainnya. Hal yang penting juga adalah melibatkan orang tua bersama dengan anak itu sendiri dalam menilai (self regulation).

Beberapa hal yang patut diketahui guru atau pembina sekolah minggu dalam melakukan penilaian haruslah berdasarkan prinsip-prinsip penilaian anak usia dini. Hal ini tertuang dalam pedoman penilaian pembelajaran PAUD yang diterbitkan oleh Direktorat Pembinaan Pendidikan Anak Usia Dini yang penulis rujuk dan sesuaikan berikut ini:

1) Mendidik. Proses dan hasil penilaian dapat dijadikan dasar untuk memotivasi, mengembangkan, dan membina anak agar tumbuh dan berkembang secara optimal. Jika terdapat nilai-nilai yang dianggap negatif berfokuslah pada perubahan positif yang ingin dicapai bukan sebaliknya. Ingatlah bahwa pikiran sendiri sangat resisten terhadap halhal negatif meskipun seseorang berusaha menghindarinya

2) Berkesinambungan. Penilaian dilakukan secara terencana, bertahap dan terus menerus untuk mendapatkan gambaran tentang perkembangan keagamaan Buddha pada diri anak

3) Objektif. Penilaian didasarkan pada prosedur dan kriteria yang jelas. Tidak dipengaruhi rasa suka dan tidak suka, sehingga dapat menggambarkan data atau informasi sesungguhnya 
4) Akuntabel. Penilaian dilaksankan sesuai dengan prosedur dan kriteria yang jelas serta dapat dipertanggung jawabkan

5) Transparan. Penilaian dilaksanakan sesuai dengan prosedur dan hasil penilaian dapat diakses oleh orang tua dan semua pemangku kepentingan yang relevan

6) Sistematis. Penilaian dilakukan secara teratur dan terprogram sesuai dengan pertumbuhan dan perkembangan anak dengan menggunakan instrumen yang tepat

7) Menyeluruh. Penilaian diupayakan mencakup semua aspek pertumbuhan dan perkembangan anak baik sikap keagamaan buddha, pengetahuan maupun keterampilan

8) Bermakna. Hasil penilaian memberikan informasi yang bermanfaat bagi anak, orang tua, guru dan pihak-pihak yang membutuhkan.

Dalam melakukan penilaian, ketrampilan yang harus benar-benar diasah oleh guru adalah keterampilan dalam melakukan pengamatan. Untuk mengamati anak, guru atau pembina sekolah minggu buddha dapat melakukan teknik (1) ceklis (2) Catatan Anekdot dan (3) Hasil Karya. Pada penilaian sikap spiritual dapat dilakukan dengan menggunakan format holistik dan analitik. Deskripsi prilaku pada format holistik maupun analitik dapat dirumuskan secara bersama antara guru dan pengelola sekolah minggu buddha dengan mengacu kepada nilai-nilai ajaran buddha yang ingin dikembangkan sesuai dengan tahapan perkembangan emosional siswa. Misalnya menggunakan empat skala sebagai berikut: 

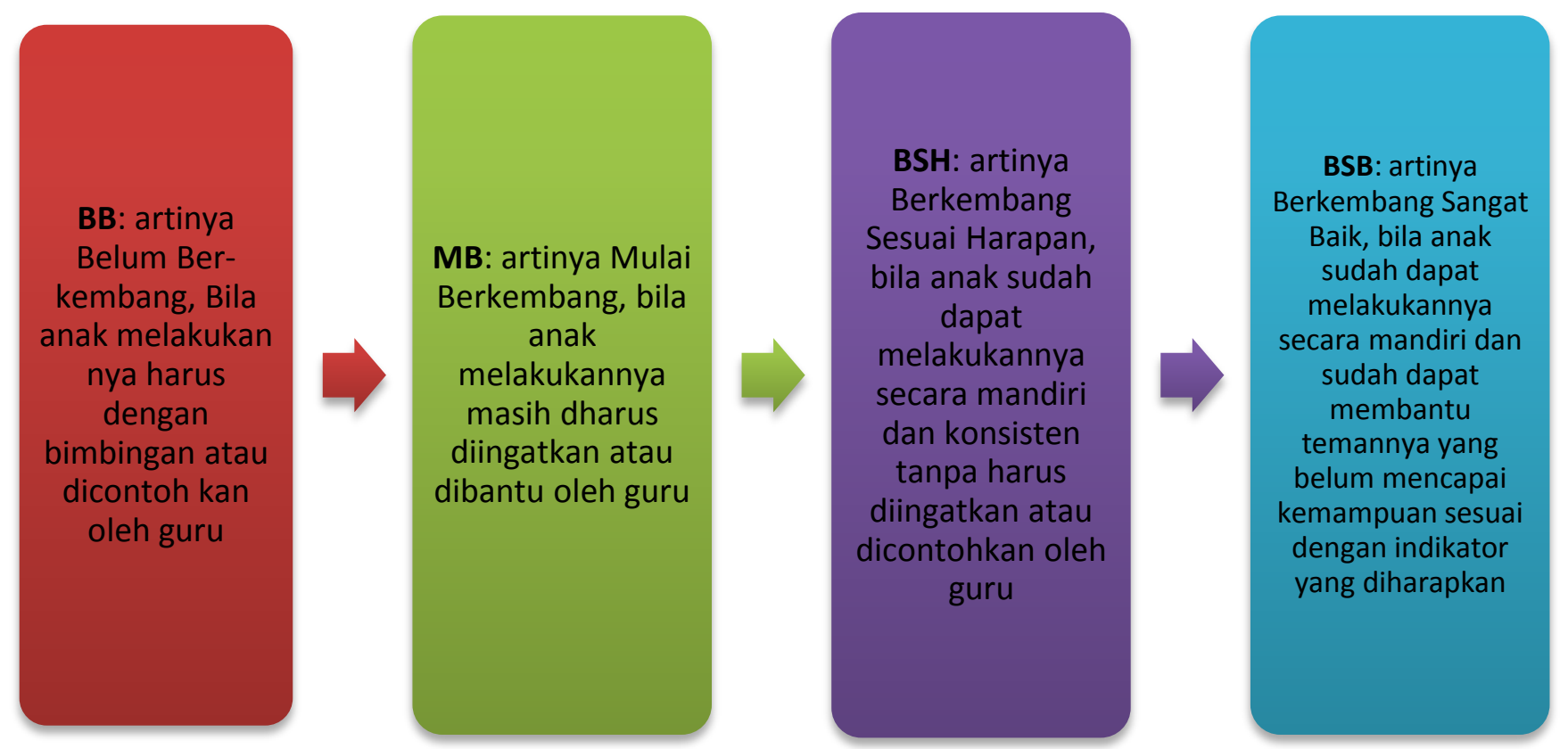

Untuk kebiasaan-kebiasaan yang negatif bisa terjadi dengan tanpa dipelajari. Sedangkan kebiasaan-kebiasaan yang negatif harus dipelajari berulang kali baik melalui contoh maupun inspirasi. Sebagai seorang Buddhis yang mungkin mengetahui tentang aspek psikologis yang terkandung di dalam pembelajaran kitab Abhidharma Tasangaha misalnya, seseorang dengan bentuk pikiran negatif lebih sedikit dibanding dengan yang netral dan positif. Namun, tetap saja sebagai manusia yang tidak terlatih akan secara alami mengarah pada pola pikiran yang negatif. Untuk itulah pembiasaan positif anakanak usia dini yang diarahkan oleh guru dan orang tua harus diupayakan mengarah pada sikap yang positif dalam menyelesaikan masalah kehidupan. Format penilaianpun harus semaksimal mungkin menggunakan kata-kata yang positif dan sesuai dengan tahap perkembangan anak usia dini.

Contoh alternatif metode penilaian sikap nilai agama Buddha dengan format Holistik sebagai berikut: 


\begin{tabular}{|c|c|c|}
\hline Nilai & Deskripsi Perilaku & Catatan \\
\hline $\begin{array}{l}\text { Berkembang } \\
\text { Sangat Baik (BSB) }\end{array}$ & & \\
\hline $\begin{array}{l}\text { Berkembang } \\
\text { Sesuai Harapan } \\
\text { (BSB) }\end{array}$ & & \\
\hline $\begin{array}{l}\text { Mulai Berkembang } \\
\text { (MB) }\end{array}$ & & \\
\hline $\begin{array}{l}\text { Belum Berkembang } \\
\text { (BB) }\end{array}$ & & \\
\hline
\end{tabular}

Contoh alternatif metode penilaian sikap nilai agama Buddha dengan format analitik sebagai berikut:

\begin{tabular}{llll}
\hline \multicolumn{1}{c}{ Aspek } & $\begin{array}{c}\text { Indikator } \\
\text { Prilaku (4 level) }\end{array}$ & Nilai & Catatan \\
\hline Meta & & \\
Karuna & & \\
Mudita & & \\
Upekha & & \\
\hline
\end{tabular}

\section{Produk(Product)}

Pada komponen produk, laporan perkembangan ini bisa dilaporkan kepada orang tua setiap enam bulan sekali. Informasi yang selaiaknya diberikan kepada orang tua tertuang dalam:

1) Buku perkembangan dan catatan ketrampilan pujabhakti, meditasi, etika dan estetika buddhis

2) Kumpulan hasil karya anak

3) Daftar cek perkembangan keagamaan buddha yang didesain sesuai tujuan

4) Data kesehatan jasmani anak (jika tersedia)

5) Informasi relevan lainnya yang digali bersama-sama dengan orang tua atau sumber lain

Diperlukan buku tuntunan pujabhakti yang sederhana penuh warna sesuai dengan anak usia dini. Buku ini sangat penting untuk dikembangkan sehingga 
pengukuran akan keterampilan anak dalam melakukan pujabhakti menjadi mudah dilakukan. Contoh buku, pengukuran meditasi dapat dilihat pada lampiran. Banyak pula pengelola sekolah minggu buddha yang mengembangkan keterampilan seni tari dan lagu bertema Buddha. Kegiatan ini sering diperlombakan di antara organisasi-organisasi pembinaan sekolah minggu buddha. Hal ini memberikan semangat dalam pengembangan sekolah minggu buddha melalui kegiatan-kegiatan serupa. Bahkan pada tingkat nasional Dirjen Bimas Buddha telah memfasilitasi kegiatan kreatif ini menjadi ajang lomba tingkat nasional.

\section{Dampak(outcome)}

Pada komponen dampak, dimaksudkan agar lembaga sekolah minggu buddha bersama-sama dengan orang tua dapat bekerja sama. Komite sekolah minggu buddha sebaiknya dibentuk dan dimaksimalkan fungsinya. Program kerja sama yang dikembangkan bersama dengan orang tua ini bisa berbentuk program keorangtuaan Buddhis (parenting education), maupun program yang berkaitan dengan kelembagaan SMB. Keduanya bersinergi satu sama lain. Program pendidikan keorangtuaan ini disusun oleh sekolah minggu buddha dengan memperhatikan keberlanjutan penanaman nilai-nilai ajaran Buddha dirumah secara kontekstual. Mengingat anak-anak lebih banyak berada di lingkungan rumah.

Setiap orang tua senantiasa memperjuangkan kebaikan masa depan anaknya.Menjadi manusia yang berbudi luhur. Bahkan meskipun bersusah payah orang tua rela mencari kebaikan bagi anaknya, Sulaiman (2015:5) dalam buku From Zero to Superhero, menceritakan kisah nyata perjuangan orang tua ini. Penulis sebagai seorang hipnoterapis aktif senantiasa mengingatkan orang tua agar tidak bertindak seperti saat mereka hendak melakukan drycelaning di tempat binatu pakaian. Anak tidak bisa diibaratkan seperti baju kotor. Saat kotor baju di cuci di binatu lantas setelah dibersihkan kembali dikotori. Sekembalinya dari sekolah minggu buddha orang tua juga harus mengetahui pola pengembangan nilai-nilai ajaran Buddha ini yang dapat dipraktikkan dalam kehidupan sehari-hari. Artinya orang tua juga sebagai model.

Pendidikan keorangtuaan diperlukan terkait perkembangan sikap religius anak. Narasumber bisa datang dari para orang tua itu sendiri maupun dari para pakar. Sedangkan perhatian terhadap kelembagaan bisa dilakukan diskusi grup terfokus untuk mengevaluasi kinerja sekolah minggu buddha. 


\section{Bagian III \\ Penutup}

Buku pedoman pelaksanaan sekolah minggu buddha, anak usia dini (adi sekha) ini merupakan pedoman yang disusun berdasarkan Studi Evaluasi terhadap Penyelenggaraan Sekolah Minggu Buddha yang ada di Kota Tangerang tahun 2015. Lembaga penyelenggara sekolah minggu buddha dapat mengembangkannya lebih lanjut sesuai dengan kemampuan yang ada. Akan tetapi tetap berpedoman pada prinsip-prinsip pendidikan anak usia dini.

Buku pedoman ini diharapkan dapat dimanfaatkan dan dikembangkan kembali oleh lembaga penyelenggara SMB, pendidik, tenaga kependidikan nonformal sejenis, dan para akademisi khususnya para mahasiswa Sekolah Tinggi Ilmu Agama Buddha.

Melalui buku ini, semoga dapat melengkapi dan membantu pemerintah,yakni Direktorat Jenderal Bimbingan Masyarakat Buddha sebagai institusi yang berfungsi mengawasi dan melakukan pembinaan. Kiranya buku ini dapat bermanfaat bagi semua pihak. 


\section{Lampiran 1}

\section{Contoh Surat Izin Operasional SMB}

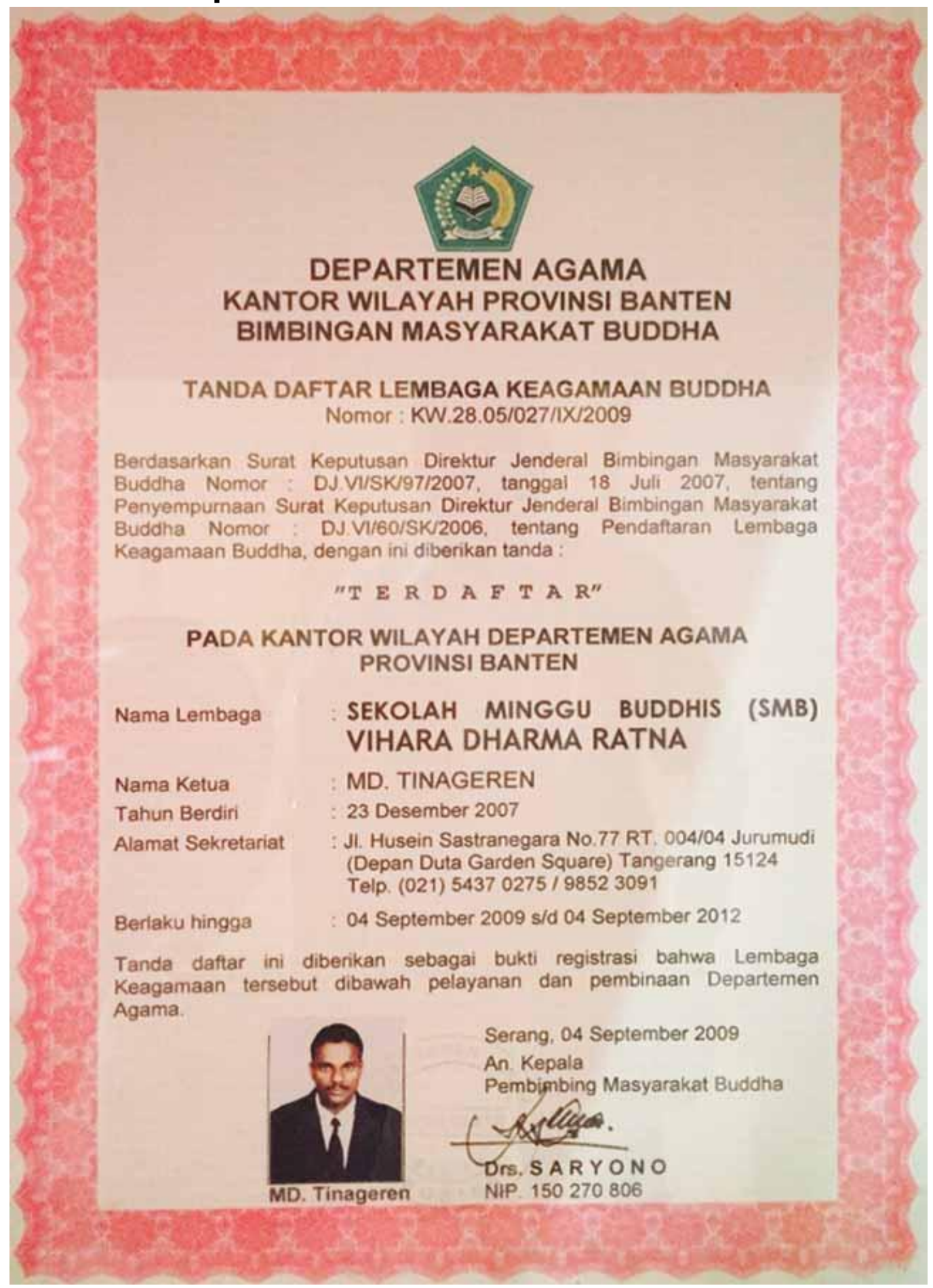




\section{Lampiran 2}

\section{Contoh Format Formulir Peserta Didik SMB}

Identitas Anak

1. Nama Lengkap

2. Nama Panggilan

3. Tempat dan Tanggal Lahir

4. Nomor dan Akte Lahir

5. Anak ke

6. Berat Badan

7. Tinggi Badan

8. Alamat Rumah

Kondisi Anak:

9. Berat badan saat lahir

10.Penyakit yang sering diderita*

11.Pantangan Makanan*

Identitas Orang Tua

12. Nama Ayah

13. Nama Ibu

14. Pendidikan Terakhir Ayah

15. Pendidikan Terakhir Ibu

16. Pekerjaan Ayah/lbu

orang tua/wali

Keterangan

Data dalam formulir ini dimasukkan ke dalam buku induk anak dan formulir isi ini diarsipkan selama lima tahun.

*Bila ada 


\title{
Lampiran 3
}

\section{Contoh Format Surat Tanda Serta Belajar}

\author{
Surat Tanda Serta Belajar \\ Nomor: ....200000210...
}

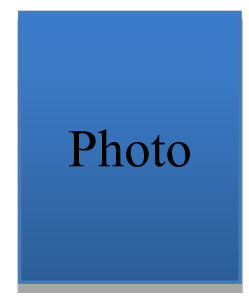

Nama

Nomor Induk

Tempat/ Tanggal Lahir

Nama Ayah

Atas keikut sertaannya secara aktif dalam program Sekolah Minggu Buddha Usia Dini (Adhi Sekha) *Dhammaratna desa Pakulonan Barat Kabupaten Tangerang

Demikian, surat tanda serta belajar ini dibuat dengan sebenarnya untuk dapat dipergunakan sebagaimana mestinya.

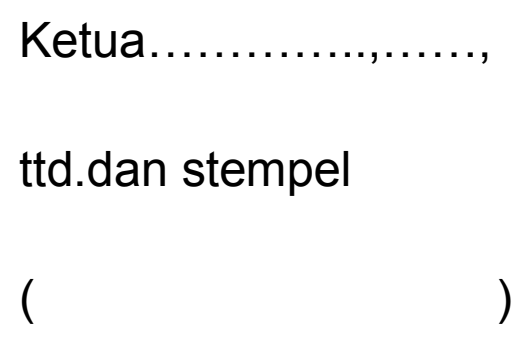

*Sesuai dengan nama sekolah minggu yang digunakan 


\section{Lampiran 4}

Contoh Rencana Pembelajaran Bulanan

\section{Kelompok Usia : 2-5 tahun}

Nama Pendidik : Rusmiati Zein

\section{Bulan}

\section{: 7,14,21 dan 28 Agustus 2015}

\begin{tabular}{|c|c|c|c|c|c|}
\hline Aspek & $\begin{array}{c}\text { Indikator } \\
\text { Perkembangan }\end{array}$ & Konsep/ Materi & Kegiatan & $\begin{array}{c}\text { Alat dan } \\
\text { Bahan }\end{array}$ & Keterangan \\
\hline $\begin{array}{l}\text { Etika dan } \\
\text { Estetika Buddhis } \\
\text { (sikap spiritual) }\end{array}$ & $\begin{array}{l}\text { 1. Mengembangkan } \\
\text { Metta } \\
\text { 2. Berbagi kepada } \\
\text { makhluk lain }\end{array}$ & $\begin{array}{l}\text { 1. Fangsen: } \\
\text { Melepas } \\
\text { Makhluk } \\
\text { hidup } \\
\text { 2. Berdana: } \\
\text { Memberi } \\
\text { makan } \\
\text { burung }\end{array}$ & $\begin{array}{l}\text { Kegiatan Guru } \\
\text { bercerita kisah } \\
\text { jataka. Member } \\
\text { makan hewan } \\
\text { sebelum } \\
\text { dilepaskan. }\end{array}$ & $\begin{array}{l}\text { Makanan } \\
\text { burung } \\
\text { dan } \\
\text { burung }\end{array}$ & $\begin{array}{l}\text { Tema: } \\
\text { Lingkungan } \\
\text { Hidup. } \\
\text { Sub Tema: } \\
\text { Pembiasaan } \\
\text { menyayangi } \\
\text { makhluk } \\
\text { hidup } \\
\text { Keg.Main: } \\
\text { Diluar } \\
\text { ruangan }\end{array}$ \\
\hline $\begin{array}{l}\text { Praktik Samadhi } \\
\text { (motorik) }\end{array}$ & $\begin{array}{l}\text { Fokus terhadap } \\
\text { sesuatu benda dalam } \\
\text { waktu tertentu }\end{array}$ & Fokus & $\begin{array}{l}\text { Siswa } \\
\text { meletakan } \\
\text { segelas air } \\
\text { mineral } \\
\text { kemasan yang } \\
\text { telah dibuka } \\
\text { diatas kepala. } \\
\text { Berjalan mulai } \\
\text { dari awal hingga } \\
\text { batas yang } \\
\text { ditentukan. }\end{array}$ & $\begin{array}{l}\text { Air mineral } \\
\text { dalam } \\
\text { kemasan } \\
\text { gelas }\end{array}$ & $\begin{array}{l}\text { Pembiasaan } \\
\text { dalam } \\
\text { melatih } \\
\text { konsentrasi }\end{array}$ \\
\hline $\begin{array}{l}\text { Pengembangan } \\
\text { kebijaksanaan } \\
\text { melalui riwayat } \\
\text { hidup Buddha } \\
\text { (kognitif) }\end{array}$ & $\begin{array}{l}\text { Mengenal kehidupan } \\
\text { masa kecil pangeran } \\
\text { Sidharta }\end{array}$ & $\begin{array}{l}\text { Menyebut } \\
\text { dengan tepat } \\
\text { kapan, dimana } \\
\text { dan } \\
\text { keterampilan } \\
\text { apa yang } \\
\text { dipelajari } \\
\text { Pangeran } \\
\text { Sidharta kecil }\end{array}$ & $\begin{array}{l}\text { Siswa melukis } \\
\text { menggunakan } \\
\text { jari gambar } \\
\text { pangeran } \\
\text { Sidharta muda }\end{array}$ & $\begin{array}{l}\text { Gambar } \\
\text { Pangeran } \\
\text { Sidharta } \\
\text { kecil. Alat- } \\
\text { alat finger } \\
\text { painting. }\end{array}$ & $\begin{array}{l}\text { Tema: } \\
\text { Riwayat } \\
\text { Hidup } \\
\text { Buddha } \\
\text { Subtema: } \\
\text { Pangeran } \\
\text { Sidharta } \\
\text { Kecil }\end{array}$ \\
\hline Seni & Bernyanyi & & & & \\
\hline
\end{tabular}

Catatan: Rencana kegiatan bulanan hendaknya dapat di integrasikan kedalam kegaitan hari minggu dengan lebih rinci. 


\section{Lampiran 5}

\section{Contoh Format Buku Induk Anak SMB}

\begin{tabular}{|c|c|c|c|c|c|c|c|c|c|c|}
\hline \multirow{2}{*}{$\begin{array}{l}\text { Tanggal } \\
\text { Terdaftar }\end{array}$} & \multirow{2}{*}{$\begin{array}{l}\text { Nomor } \\
\text { Induk }\end{array}$} & \multirow{2}{*}{$\begin{array}{c}\text { Nama } \\
\text { Anak }\end{array}$} & \multirow{2}{*}{$\begin{array}{l}\text { Tempat\& } \\
\text { Tgl.Lahir }\end{array}$} & \multirow{2}{*}{ L/P } & \multirow{2}{*}{$\begin{array}{l}\text { No. Akte } \\
\text { Kelahiran }\end{array}$} & \multirow{2}{*}{ Alamat } & \multicolumn{3}{|c|}{ Identitas Orang Tua } & \multirow{2}{*}{$\begin{array}{l}\text { Tanggal } \\
\text { Berhenti }\end{array}$} \\
\hline & & & & & & & Nama & Pekerjaan & Pendidikan & \\
\hline \multirow[t]{2}{*}{$\overline{15 / 01 / 15}$} & \multirow[t]{2}{*}{20020} & \multirow{2}{*}{$\begin{array}{l}\text { Andi } \\
\text { Reza }\end{array}$} & \multirow{2}{*}{$\begin{array}{l}\text { Kotu, } \\
13 / 01 / 11\end{array}$} & \multirow[t]{2}{*}{$\bar{L}$} & & & Kapoor & Enginering & STM & \\
\hline & & & & & & & Karina & PNS & SMK & \\
\hline & & & & & & & & & & \\
\hline & & & & & & & & & & \\
\hline & & & & & & & & & & \\
\hline & & & & & & & & & & \\
\hline & & & & & & & & & & \\
\hline
\end{tabular}

\section{Keterangan:}

1. Nomor Induk Anak digunakan secara berkelanjutan

2. Nomor Induk Anak diurut berdasarkan pendaftaran

3. Buku Induk ini dapat berbentuk buku besar bergaris atau kumpulan data cetak/print 


\section{Lampiran 6}

\section{Contoh Format Daftar Hadir Anak SMB}

\section{Bulan: Februari 2015}

\begin{tabular}{|c|c|c|c|c|c|c|c|}
\hline \multirow{2}{*}{ No. } & \multirow{2}{*}{$\begin{array}{l}\text { Nomor } \\
\text { Induk }\end{array}$} & \multirow{2}{*}{ Nama } & \multicolumn{4}{|c|}{ Tanggal } & \multirow{2}{*}{$\begin{array}{l}\text { Tanggal } \\
\text { Berhenti }\end{array}$} \\
\hline & & & 7 & 14 & 21 & 28 & \\
\hline 1. & 20001 & Suryadi & & & & & \\
\hline 2. & & & & & & & \\
\hline 3. & & & & & & & \\
\hline 4. & & & & & & & \\
\hline 5. & & & & & & & \\
\hline
\end{tabular}

Keterangan:
1. I = ljin
2. $M=$ Masuk
3. $S=$ Sakit
4. $A=$ Alpha 


\section{Lampiran 7}

Contoh Format Buku Pengelola dan Pendidik SMB

\begin{tabular}{|l|l|l|l|l|l|l|l|l|l|}
\hline No. & $\begin{array}{l}\text { Tanggal } \\
\text { Terdaftar }\end{array}$ & $\begin{array}{c}\text { Nomor } \\
\text { Induk }\end{array}$ & Nama & $\begin{array}{l}\text { Tempat\& } \\
\text { Tgl.Lahir }\end{array}$ & L/P & Alamat & Pendidikan & $\begin{array}{c}\text { Pelatihan } \\
\text { (S/B) }\end{array}$ & $\begin{array}{c}\text { Tanggal } \\
\text { Berhenti }\end{array}$ \\
\hline 1 & $21 / 06 / 11$ & 201101 & Yusniati & $\begin{array}{l}\text { Rantau, } \\
21 / 06 / 1985\end{array}$ & P & $\begin{array}{l}\text { Rantau } \\
\text { Rt.05 } \\
\text { No6 }\end{array}$ & SGPAUD & Sudah & \\
\hline & & & & & & & & & \\
\hline & & & & & & & & & \\
\hline & & & & & & & & & \\
\hline
\end{tabular}

\section{Keterangan:}

1. Buku data pengelola SMB digunakan secara berkelanjutan.

2. Nomor Induk pengelola dan pendidik berdasarkan pada urutan pendaftaran

3. Buku dapat dibuat dari buku besar bergaris atau dari kumpulan data yang dicetak/print 


\section{Lampiran 8}

\section{Contoh Format Daftar Hadir Pengelola SMB}

\section{Bulan: Februari 2015}

\begin{tabular}{|c|c|c|c|c|c|c|c|}
\hline \multirow{2}{*}{ No. } & \multirow{2}{*}{$\begin{array}{l}\text { Nomor } \\
\text { Induk }\end{array}$} & \multirow{2}{*}{ Nama } & \multicolumn{4}{|c|}{ Tanggal } & \multirow{2}{*}{$\begin{array}{l}\text { Tanggal } \\
\text { Berhenti }\end{array}$} \\
\hline & & & 7 & 14 & 21 & 28 & \\
\hline 1. & 20001 & Andrew Wijaya & & & & & \\
\hline 2. & & & & & & & \\
\hline 3. & & & & & & & \\
\hline 4. & & & & & & & \\
\hline 5. & & & & & & & \\
\hline
\end{tabular}

Keterangan:
1. I = ljin
2. $M=$ Masuk
3. $S=$ Sakit
4. $A=$ Alpha 


\section{Lampiran 9}

Contoh Format Kartu Dana Paramitha Bulanan SMB

Nama Anak : Januari 2016

Nama Orang Tua

\begin{tabular}{|l|l|l|l|l|}
\hline No & \multicolumn{1}{|c|}{ Bulan } & Tanggal Berdana & Jumlah Uang & Parah Penerima \\
\hline 1 & Juli & & & \\
\hline 2 & Agustus & & & \\
\hline 3 & September & & & \\
\hline 4 & dst. & & & \\
\hline
\end{tabular}

\section{Keterangan:}

1. Diadakannya dana paramitha bulanan ini tidak mengikat dan diluar dana pramitha saat pujabhakti berlangsung yang dilakukan oleh anak-anak

2. Besaran Dana Paramitha dapat disepakati para pengelola misalnya minimal Rp.5000,-

3. Dana ini dapat digunakan mendukung operasional maupun kegiatan SMB 


\section{Lampiran 10}

Contoh Format Buku KAS SMB

Bulan: Januari 2016

Penerimaan:

Pengeluaran:

\begin{tabular}{|c|c|c|c|c|c|c|c|}
\hline Tanggal & $\begin{array}{c}\text { No. } \\
\text { Bukti } \\
\text { Kas }\end{array}$ & Uraian & $\begin{array}{c}\text { Jumlah } \\
\text { Uang }\end{array}$ & Tanggal & $\begin{array}{c}\text { No. } \\
\text { Bukti } \\
\text { Kas }\end{array}$ & Uraian & $\begin{array}{c}\text { Jumlah } \\
\text { Uang }\end{array}$ \\
\hline & & & & & & & \\
\hline & & & & & & & \\
\hline & & & & & & & \\
\hline
\end{tabular}




\section{Lampiran 11}

Contoh Format Buku Inventaris SMB

\begin{tabular}{|c|c|c|c|c|c|c|c|}
\hline \multirow[b]{2}{*}{ No. } & \multirow{2}{*}{$\begin{array}{l}\text { Tanggal } \\
\text { Perolehan }\end{array}$} & \multirow{2}{*}{$\begin{array}{l}\text { Nama } \\
\text { Barang }\end{array}$} & \multirow[b]{2}{*}{ Jumlah } & \multirow{2}{*}{$\begin{array}{c}\text { Asal } \\
\text { Barang }\end{array}$} & \multicolumn{3}{|c|}{ Penghapusan Barang } \\
\hline & & & & & Jumlah & $\begin{array}{l}\text { Tanggal } \\
\text { Dihapuskan }\end{array}$ & Keterangan \\
\hline 1. & "01/02/2015 & $\begin{array}{l}\text { Mainan } \\
\text { Gantung }\end{array}$ & 2 & $\begin{array}{l}\text { Donasi } \\
\text { Kel.Ibu } \\
\text { Ani }\end{array}$ & 1 & "02/02/2016 & Rusak \\
\hline 2. & $02 / 03 / 2015$ & $\begin{array}{l}\text { Boneka } \\
\text { Buddha }\end{array}$ & 10 & Karaniya & & & \\
\hline 3. & dst. & & & & & & \\
\hline
\end{tabular}




\title{
Lampiran 12
}

Contoh Laporan Perkembangan Anak Sekolah Minggu Buddha

\author{
Nama : Anjalika \\ Nomor Induk : 2010001 \\ Kelompok : Adi Sekha Usia 2-4 tahun \\ Semester : 1
}

A. Informasi Perkembangan

\begin{tabular}{|c|c|}
\hline No. & Aspek Perkembangan dan Pencapaiannya \\
\hline 1. & $\begin{array}{l}\text { Membaca Parita Suci } \\
\text { - Anak sudah dapat melakukan sikap namaskara dengan baik } \\
\text { - } \quad \text { Sudah dapat melafalkan doa Namakarapatta }\end{array}$ \\
\hline 2. & $\begin{array}{l}\text { Simbol Buddhis } \\
\text { - Anak dapat menyebutkan warna-warni bendera Buddhis } \\
\text { - Menyebutkan bentuk stupa }\end{array}$ \\
\hline 3. & $\begin{array}{l}\text { Etika dan Estetika Buddhis } \\
\text { - Memberikan salam hormat "Namo Buddhaya, Terpujilah Buddha" } \\
\text { di hadapan altar Buddha } \\
\text { - Memberikan salam hormat kepada Guru "Namaste" }\end{array}$ \\
\hline 4. & dst. \\
\hline
\end{tabular}

B. Informasi Kehadiran : Sakit 1 hari ...

C. Rekomendasi untuk orang tua

1. Mari ajak anak bersama-sama membaca perita suci singkat sebelum tidur

2. Lebih disiplin ceklis tugas perkembangan keagamaan anak

Sukasari, 13 Juli 2015

Orang tua,

Guru Kelas

(Susilawati, S.Pd.) 


\section{Lampiran 13}

Contoh Ruang Kelas, Ruang Guru dan Aktivitas Belajar SMB Anak Usia Dini

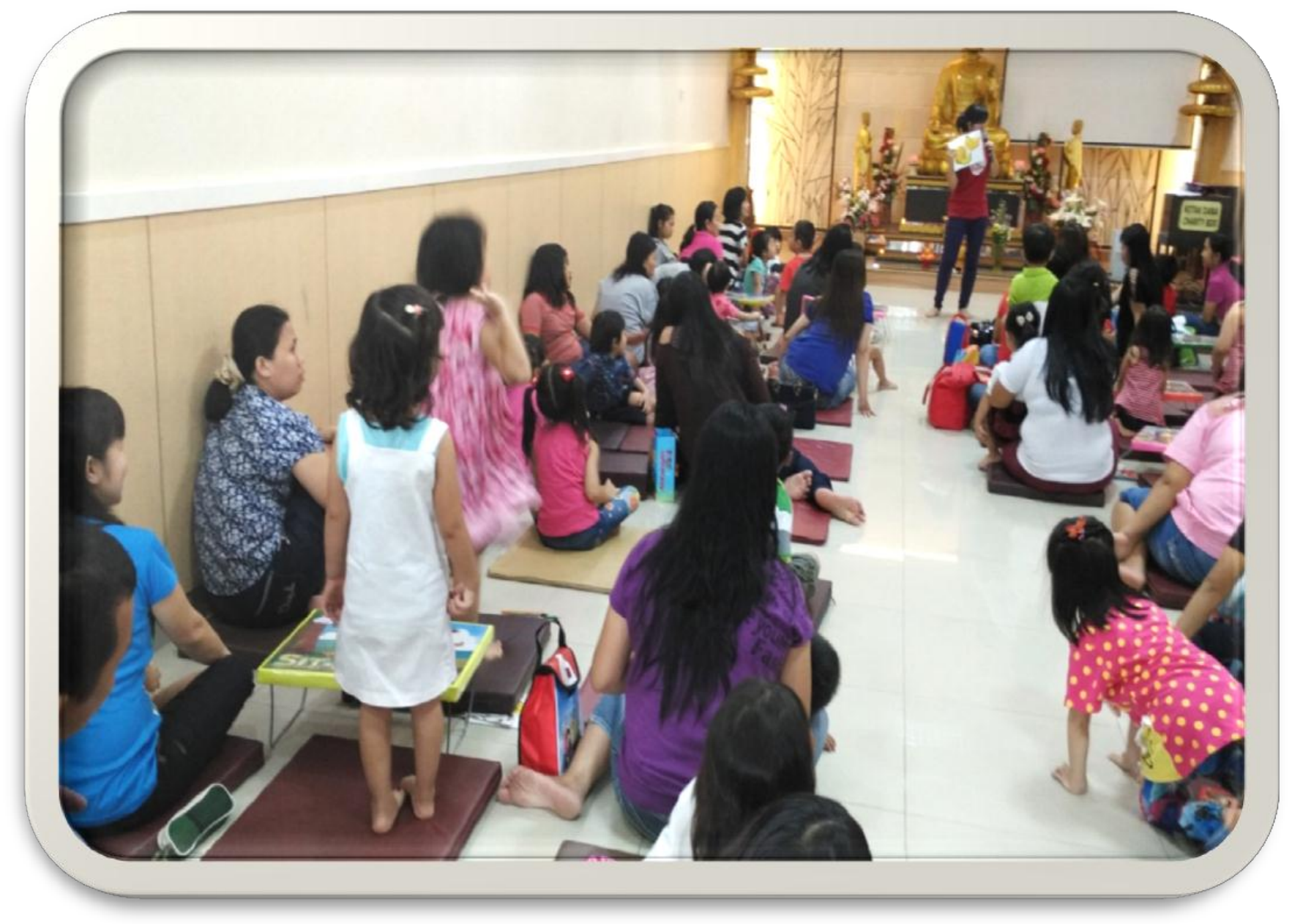



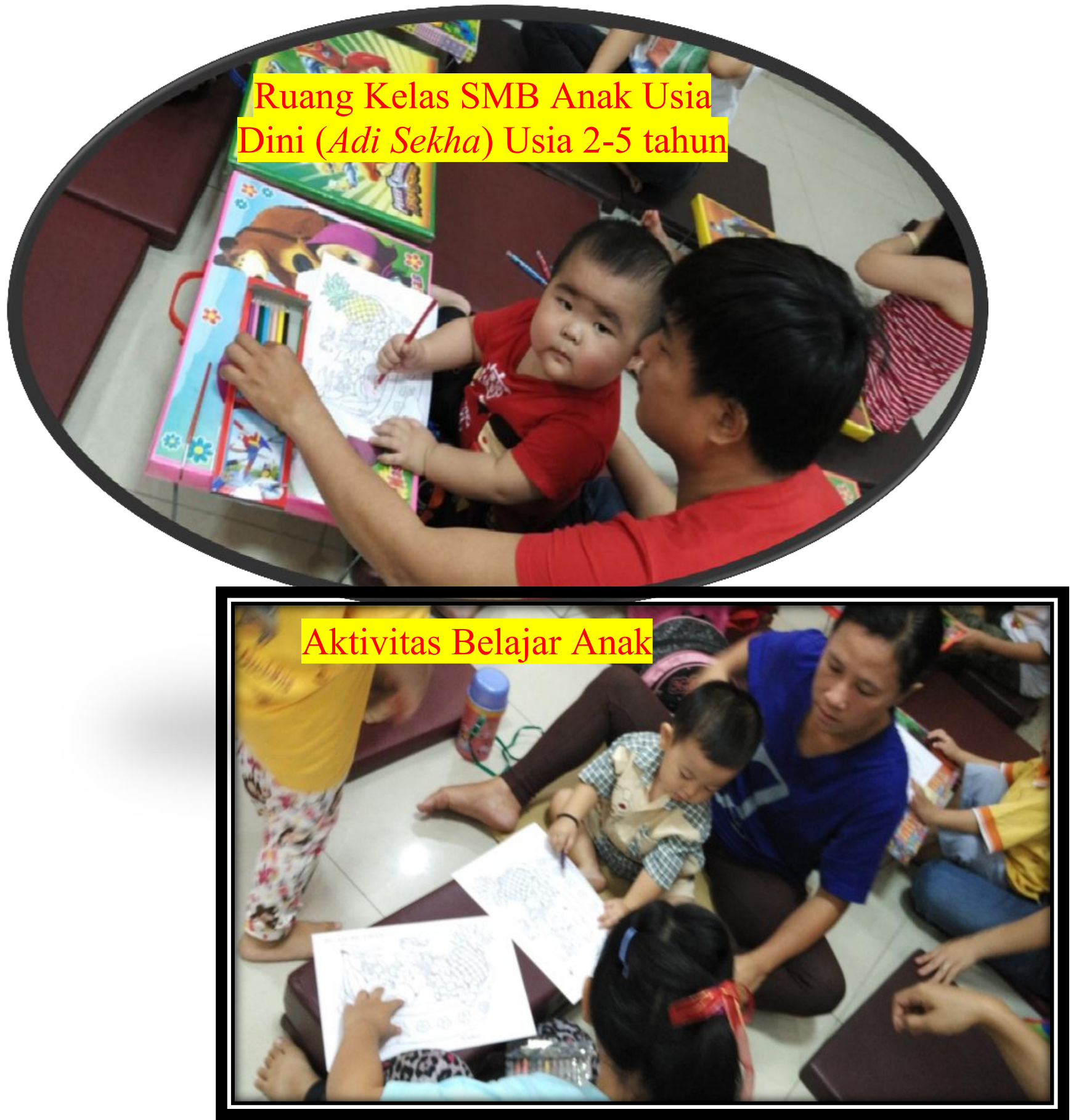

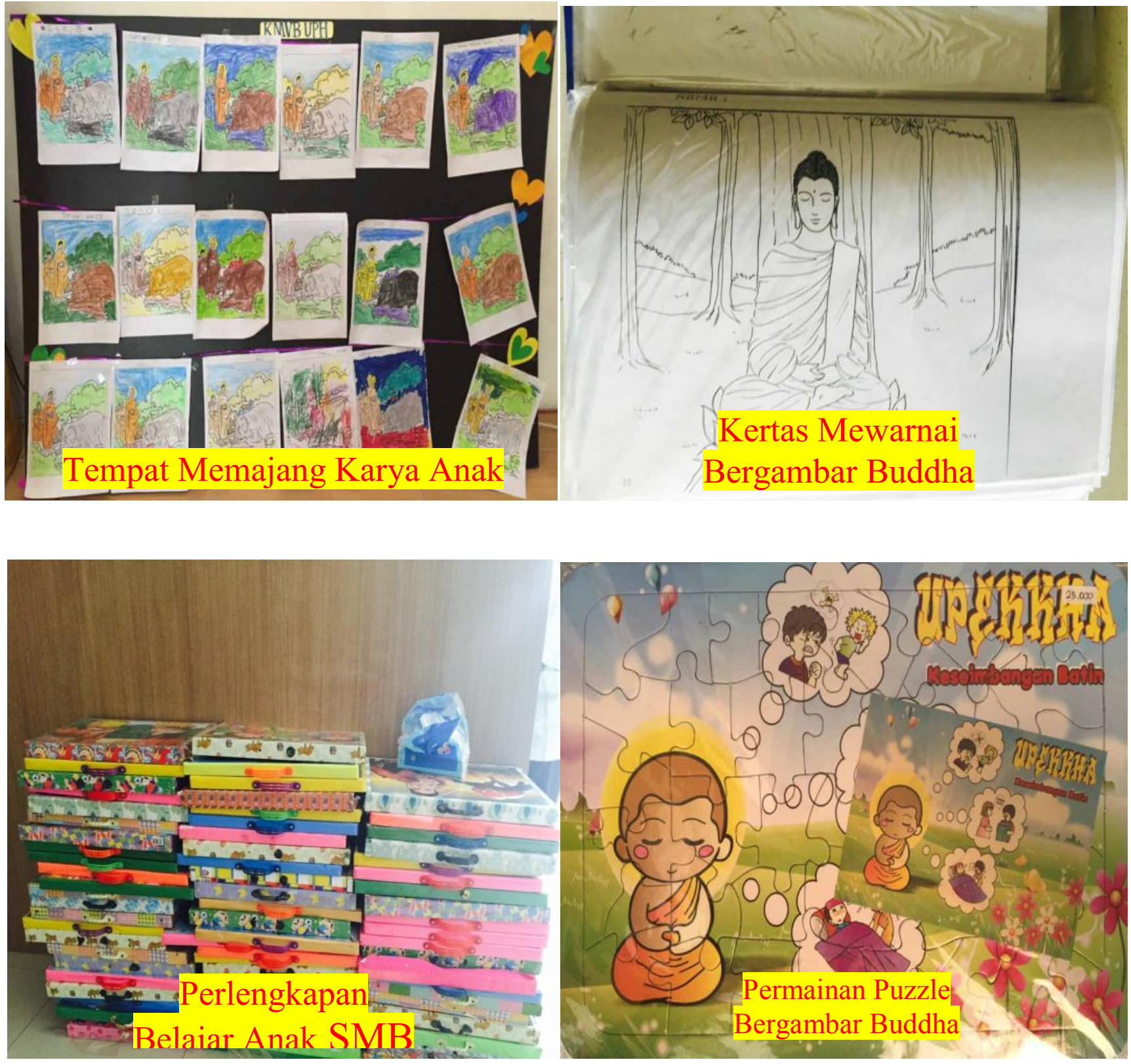


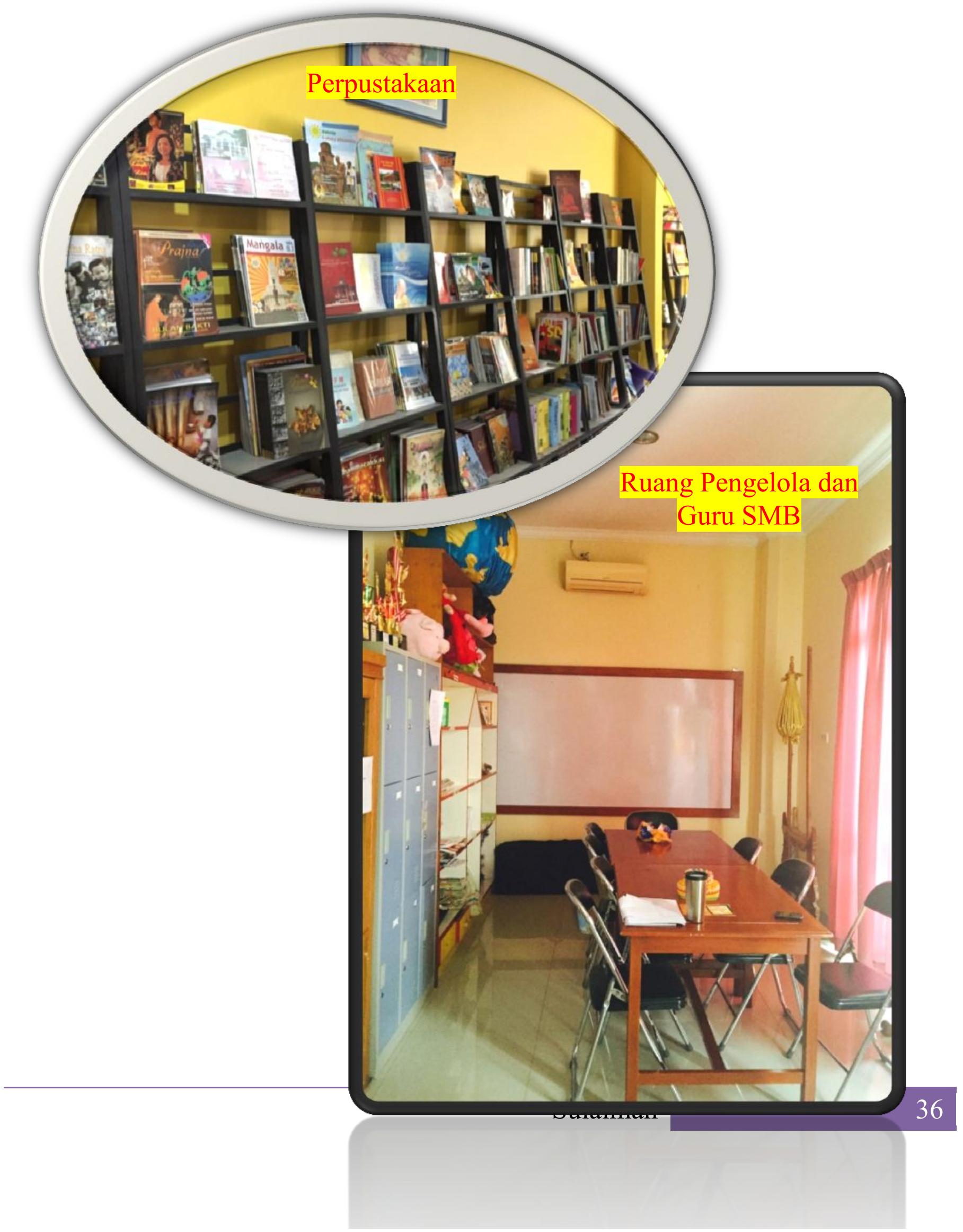




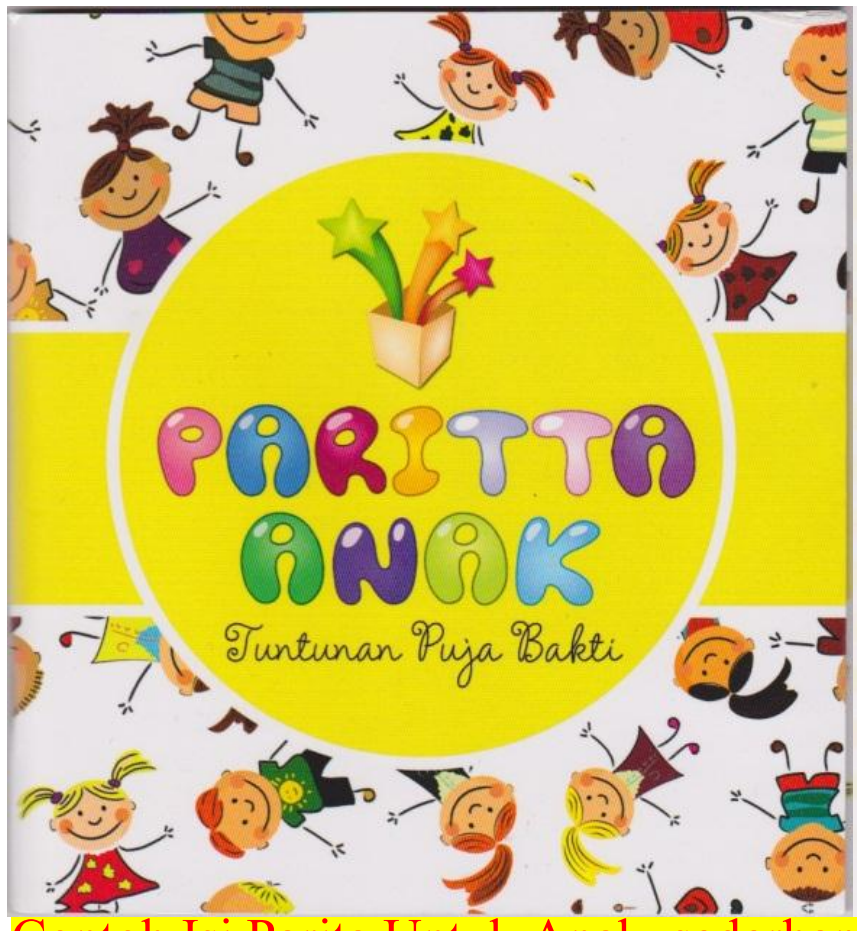

\section{MENGriomas DENGEN BENET}

Yang perlu kita tahu sebelum membaca paritta

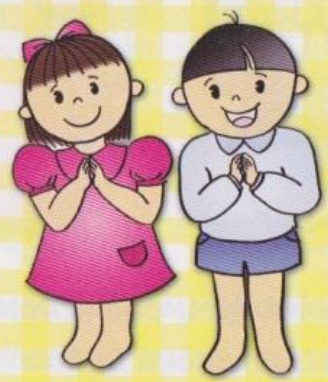

Contoh Isi Parita Untuk Anak, sederhana bagi anak Usia Dini dan Penuh Warna
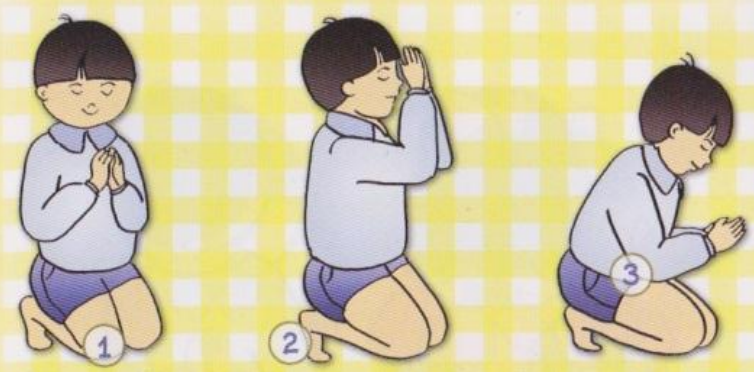

NaMaKāRa Yang BENaR ADa 5 TiTiK YaNG HaRUS MENYENTUH LaNTai
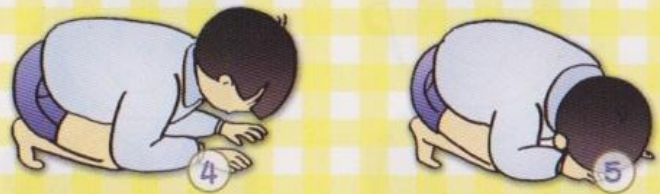

5 TiTiK iTU aDaLaH:

LUTUT, UJUNG JaRi-JaRi KaKi, SiKu TELaPaK TaNGaN DaN DaHi
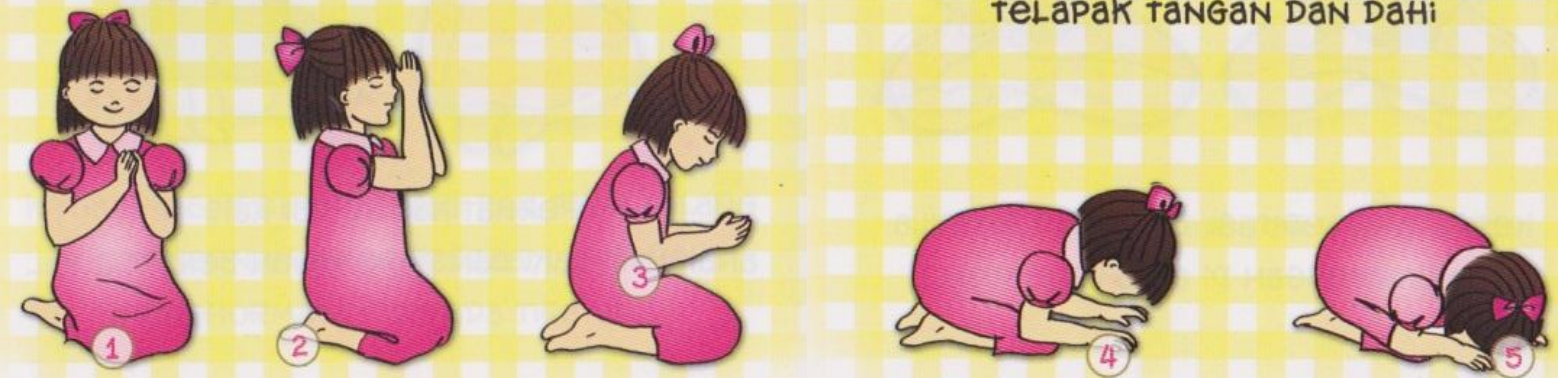

Contoh Isi Parita Untuk Anak, Sumber: Menanam Kebajikan 


\section{Daftar Referensi}

Arikunto, Surahsimi dan Safrudin A.J., Cepi. Evaluasi Program Pendidikan, Jakarta:Bumi Aksara, 2014

Arsyad, Prof. Dr. Azhar, M.A, Media Pembelajaran, PT. Raja Grafindo Persada, 2011

Bennett, Judith. Evaluation Methods in Research, London:Continuum,2003 Pearson Merril Prentice Hall Inc, 2006

Gardner, Don.E., dalam Mutrofin. Evaluasi Program. Teks Pilihan untuk pemula Yokyakarta:Laksbang Presindo, 2010

Girivirya, Sulaiman. From Zero to Superhero, Jakarta:Elex Media Computindo,2014

http://bimasbuddha.kemenag.com

Jalal, Fasli "Sambutan Pada Upacara Peringatan Hari Keluarga Nasional XXI Tahun 2014," Jakarta, BKKBN

Jamaris, Martini, Perkembangan dan Pengembangan Anak Usia Taman to Early Childhood Curriculum, Pearson Merrill Prentice Hall, Ohio, 2008

Kusaladhamma, Bikkhu. Kronologi Hidup Buddha, Jakarta:Ehipassiko Foundation,2004

Suyadi, Psikologi Belajar Pendidikan Anak Usia Dini, Yogyakarta:Pedagogia, 2010

Sukardi, Evaluasi Program Pendidikan dan Pelatihan, Jakarta:Bumi Aksara,2014

Undang-undang Sistem Pendidikan Nasional No.20 tahun 2003, tentang pendidikan nasional, Pasal 1, Butir 14 


\section{Tentang Penulis}

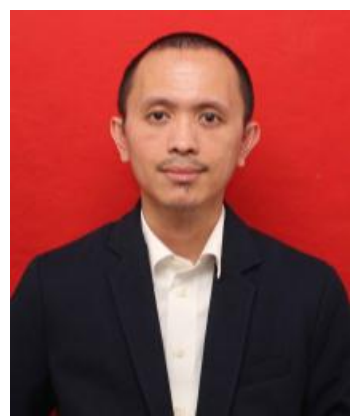

Sulaiman, Putra pertama dari pasangan Ujang Efendi (Alm.) dan Hj. Sumardiana. Lahir di Palembang, 13 November 1985. Menyelesaikan pendidikan dasar hingga menengah di Kota Lubuk Linggau, Sumatera Selatan.

Dalam perjalanannya sebagai pencari makna kehidupan, la bergabung di Kelompok Monastik. Melanjutkan pendidikan di perguruan tinggi, Universitas PGRI Palembang, selesai tahun 2009. Menyelesaikan Magister Pendidikan (M.Pd.), Universitas Jambi, pada tahun 2011. Pengalaman traumatis dengan Ibu Guru Matematika di sekolah dasar mendorongnya untuk berdedikasi sebagai "Guru". Menjadi Guru bukan sekedar profesi namun dedikasi penuh makna.Baginya Guru adalah penghapus kegelapan.Maka, menjadi Guru berarti memperbaiki diri sendiri. Baginya, menimba ilmu pada program doktoral anak usia dini, Universitas Negeri Jakarta merupakan berkah dan rasa syukur yang tidak terhingga. Dengan ilmu ini dapat mendedikasikan dirinya lebih baik lagi bagi Generasi Emas Indonesia 2045.

Mendalami Teknologi Pikiran sejak tahun 2006, bergabung pada lembaga hipnoterapis klinis ternama di Indonesia tahun 2009 dan Certified Trainer dari lembaga Adi W. Gunawan Institute of Mind Technology. Kecintaan pada dunia pengembangan diri membuahkan karya tulis inspiratif besama kakak perempuannya Hj.Sulastri,Lc.,M.Pd.I., "Main-main dengan Mind: Kekuatan Meditasi dan Dzikir", di tahun 2011, yang diterbitkan oleh Penerbit Nasional Elex Media Komputindo. Dari karya ini berkesempatan berbicara di berbagai panggung dan dipercaya memberikan pelatihan Coping Stress bagi Dosen dan Rektorat di almamaternya, Universitas Jambi.

Hobi bertualang, dimulai dari penulis semasa SMP dengan menjadi ketua sangha di Kepramukaan.Berbicara dan mengajar juga menjadi aktivitasnya dimulai sekolah menengah.Beberapa karyanya adalah artikel dan karya-karya suntingan.Peneliti dapat dihubungi melalui email: girivirya@yahoo.com.fb.Page: facebook.com/Giriviryas/. 


\section{Model Evaluasi Sekolah Minggu Buddha (SMB)}

adalah model konseptual dalam melakukan evaluasi Pendidikan Sekolah Minggu Buddha (SMB) dengan tahapan Context (Konteks), Input (Masukan), Process (Proses), dan Outcome (Luaran). Kerangka model SMB dikembangkan dari modifikasi model evaluasi Stufflebeam (1985) dengan penambahan unsur Outcome atau Luaran yang ada di SMB yaitu Orangtua.

\section{Dr. Sulaiman, Ph.D (c.)}

Dosen STABN Sriwijaya bidang Kajian Agama dan Pendidikan Keagamaan. Kandidat Doktor, (Ph.D. Program) College of Religious Studies, Mahidol University Thailand. Menyelesaikan Doktor Teknologi Pendidikan Konsentrasi Pendidikan Anak Usia Dini, Universitas Negeri Jakarta tahun 2016 dengan predikat Cumlaude dibiayai dari beasiswa Lembaga Pengelola Dana Pendidikan (LPDP). Seorang Mindtech. Minat pada bidang kajian Agama dan Pendidikan Agama membuat la menulis buku Inspiratif "Main-main dengan MIND Kekuatan Meditasi dan Dzikir", bersama kakak perempuannya Hj. Sulastri, Lc., M.Pd.I.

Laman Web http://grahanyana:com fb.: facebook.com/grahanyana youtube: https://www.youtube.com/ channel/UCj6dyoy3lliCFfr8hjxwnMg/

ISBN 978-602-52670-7-9

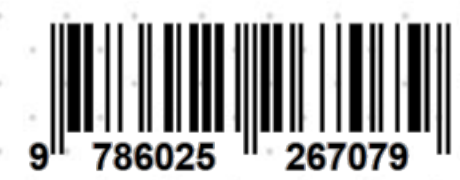

Referensi: Orangtua, Mahasiswa Sarjana, dan Guru 